\title{
DIRECTORY OF ACCREDITED NORTH AMERICAN QUALITY SYSTEM REGISTRATION ORGANIZATIONS (NAQSRO)
}

Michael E. Squires

United States Department of Commerce National Institute of Standards and Technology Standards Services Division Technology Services Gaithersburg, MD 20899 USA 

NISTIR 65152002 ED

\title{
DIRECTORY OF ACCREDITED NORTH AMERICAN QUALITY SYSTEM REGISTRATION ORGANIZATIONS (NAQSRO)
}

\author{
Michael E. Squires \\ U.S. Department of Commerce \\ National Institute of Standards and Technology \\ Standards Services Division \\ Technology Services \\ Gaithersburg, MD 20899 USA
}

August 2002

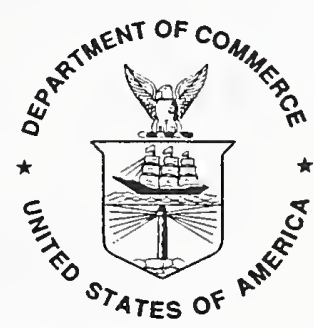

U.S. DEPARTMENT OF COMMERCE

Donald L. Evans, Secretary TECHNOLOGY ADMINISTRATION

Phillip J. Bond, Under Secretary of Commerce for Technology NATIONAL INSTITUTE OF STANDARDS AND TECHNOLOGY Arden L. Bement, Jr., Director 


\section{TABLE OF CONTENTS}

ABSTRACT $\ldots$

ABS Quality Evaluations. Inc. (ABS QE) $\ldots \ldots \ldots$

Advanced Waste Management Systems. Inc. (AWMS) $\ldots \ldots \ldots$

AEA Quality Advantage Corporation (AEA) ...................... 2

AFAQ-ASCERT International. Inc. (AAI) $\ldots$

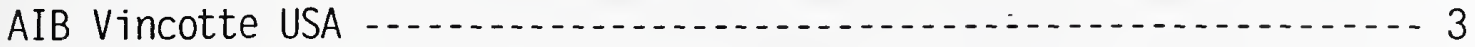

Amador Product Service (See TUV Management Services) .............. 4

American Global Standards (AGS) ............................ 4

American Institute of Quality Registrars (AIQR) $\ldots \ldots \ldots$

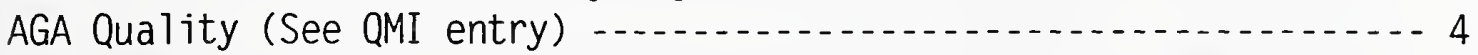

American Petroleum Institute Quality Registrar (APIQR) _........ 4

American Quality Assessors (AQA) ........................... 5

American Society of Mechanical Engineers (ASME International) ..... 6

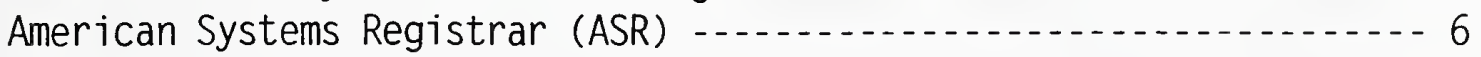

AOQC Moody International. Inc. - United States -............. 6

AOQC Moody International Registration Ltd. (AOQC) - Canada -....... 7

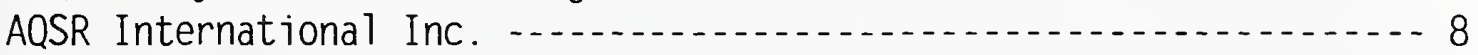

AV Qualite (AVQ) (See Det Norske Veritas Certification. Inc./DNV) - 8 BQR. Ltd. -BestCERT Quality Registrars Ltd. (BQR) .............. 8 Bellcore Quality Registration Services (See Telcordia Quality

Registration) -... 9

BSI, Inc. (BSI, Inc.) $\ldots$

Bureau de normalisation du Quebec - Systems registration (BNQ-SR) - 10

Bureau Veritas Quality International (N.A.) Inc. (BVQI)-SR ....... 11

Calidad Mexicana Certificada, A.C. (CALMECAC) ................... 12

Canadian General Standards Board (CGSB)

Certech Registration Inc. ................................... 13

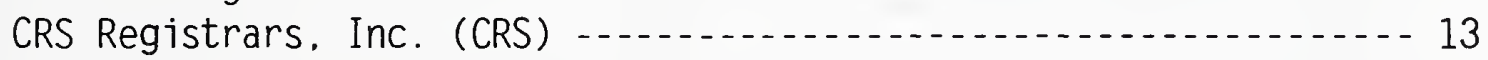

Davy Scott Registrars. Inc. (DRS) (See American Global Standards) - 14

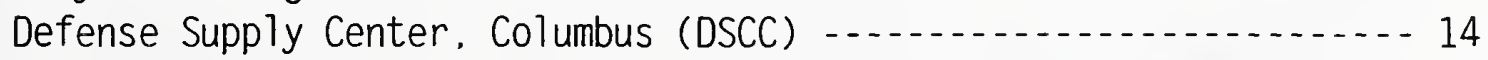

Deloitte \& Touche Quality Registrar Inc. (D\&T QRI) .......... 15

Det Norske Veritas Certification. Inc. (DNV)

DLS Quality Technology Associates. Inc. (DLS)

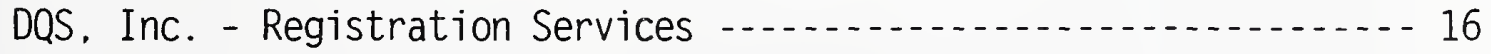

EAGLE Registrations, Inc.

EAQA USA Registrars, Inc.

Emaco Product Service (See TUV Management Services) ............. 18 
Entela, Inc. QSRD $\ldots \ldots \ldots \ldots$

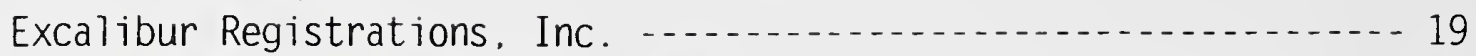

Factory Mutual Research Corp. (FMRC)

GBJD Registrars Ltd.

Global Registrars, Inc. (GRI) - 20

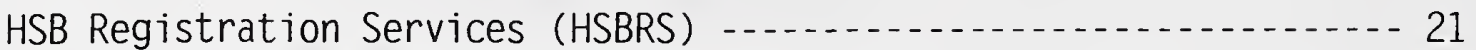

International Approval Services. Inc. (IAS) -

Instituto Mexicano de Normalizacion y Certificacion. A.C. (IMNC) - 21

International Quality Certifications, S.A., DE C.V. (IQC) -

International Management Systems. Inc. (IMS) .................. 22

International Quality Registrars Corp. (IQR) -

International Quality System Registrars (IQSR) - .

International Standards Authority (ISA) -

ITS Intertek Services (ITS) - ........... 24

Intertek Testing Services, NA, Ltd.

ISOQAR, Inc. (ISOQAR) - 26

KEMA Registered Quality (KRQ) $\ldots \ldots$

Kemper Registrar Services (See Bureau Veritas Quality International

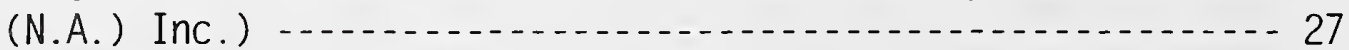

KPMG Quality Registrar (KPMGQR)

LLD, Inc. -....... 28

Lloyd's Register Quality Assurance, Ltd. (LRQA) .............. 28

National Quality Assurance, U.S.A. (NQA, USA) $\ldots \ldots$

NSF International Strategic Registrations, Ltd. (NSF-ISR) - $\ldots \ldots$

National Standards Authority of Ireland (NSAI)

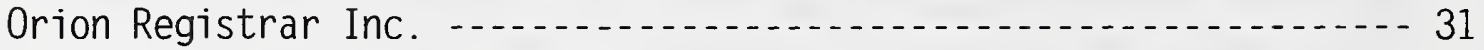

OTS Quality Registrars (OTSQR)

Performance Review Institute Registrar (PRI) ......... 32

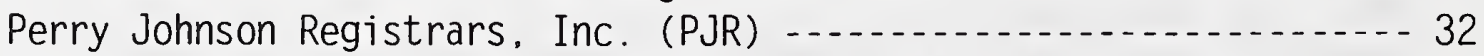

Professional Registrar Organization. Inc. (PRO, INC) $\ldots \ldots \ldots$

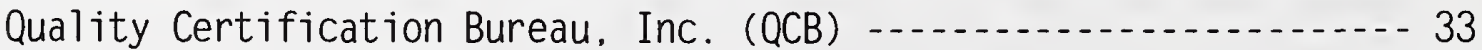

Quality Management Institute (QMI) -

Quality Services International (QSI) $\ldots \ldots \ldots$

Quality Systems Registrars, Inc. (QSR) $\ldots \ldots \ldots$

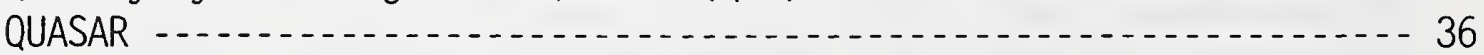

SGS International Certification Services Inc. (SGS ICS) ......... 37

SGS International Certification Services, Inc. (SGS ICS, Inc.) -..- 38

Smithers Quality Assessments, Inc. (SQA) .................. 38

SRI Quality System Registrar. Inc. (SRI)

STR-Registrar, LLC $\ldots$

Telcordia Quality Registration (TQR)

The Registrar Company. Inc. (TRC) 40

TRA Certification (TRA-CD) -

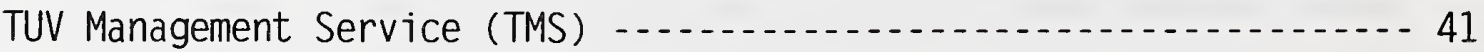

TUV CETECOM - 
TUV Rheinland of North America. Inc. (TUVRNA) _................ 43 Underwriters Laboratories. Inc. (UL) _......................... 44 Underwriters' Laboratories of Canada (ULC) - ................. 45 United Registrar of Systems Ltd. (URS) _........................ 45 U.S. Testing Company (See SGS Int'1. Certification Services) -..... 46

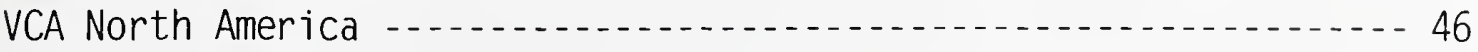

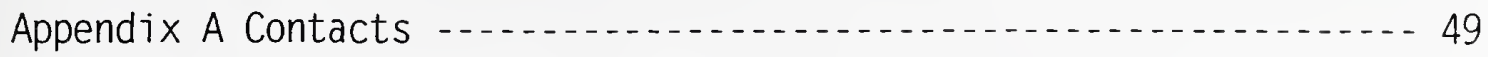

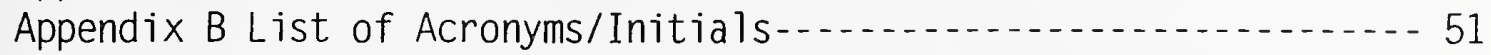

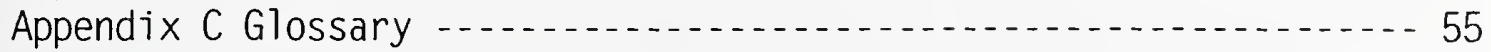




\title{
ABSTRACT
}

This publication contains information on accredited management system registrars ${ }^{1}$ located in the United States, Canada and Mexico. The information was provided to the National Institute of Standards and Technology (NIST) by the accredited organizations. NO ATTEMPT HAS BEEN MADE TO EVALUATE ANY OF THESE PROGRAMS. The information on each organization includes: their accreditation(s), other forms of recognition, and the scope of their management system assessment and registration services. Organizations were asked to indicate if they provide assessment and registration services to: ANSI/ASQ (American Society for Quality) Q9001; ISO (International Organization for Standardization) 9001; QS (Quality Systems) 9000 and ISO TS (Technical Specification) 16949 for the auto industry; TL (Telecommunications) 9000; the ISO 14000 Standards Series for Environmental Management Systems (EMS); Hazard Analysis Critical Control Point (HACCP) requirements for the food industry; SA (Social Accountability) 8000; or to other related standards.

Interested parties are advised to review and compare the offered services (particularly the registrars' scopes of accreditation) when selecting a program appropriate to their needs.

For additional information, contact:

\author{
Michael Squires \\ National Institute of Standards and Technology (NIST) \\ 100 Bureau Drive, Mail Stop 2150 \\ Gaithersburg, MD 20899-2150 \\ Telephone: (301) 975-4039 \\ Fax: (301) 926-1559 \\ E-mail: michael.squires@nist.gov
}

Disclainer: Readers are reminded that the information in this directory is based on information provided by each organization and reflects the organization's view of its activities. No attempt was made by NIST to evaluate the services provided by these organizations.

\footnotetext{
${ }^{1}$ The directory also includes registrars that have provided evidence that they are actively pursuing national accreditation.
} 

1) ABS Quality Evaluations, Inc. (ABS QE)

16855 Northchase Drive

Houston, TX 77060-6008

Phone: (281) 877-6800 (Contact: Patricia L. Wigginton)

Fax: (281) 877-6801

E-Mail: ge cust serv@eagle.org

URL: www.abs-qe.com

Other Information:

a. Accredited by: RvA (Raad voor Accreditatie) (Netherlands) and INMETRO (Instituto de Metrologia, Normalizacao e Qualidade Industrial) (Brazil). Accredited by ANSI-RAB NAP for ISO 9000 and 14000.

b. Other Program Recognition: QS-9000 qualified registrar by Ford/DaimlerChrysler/GM (General Moł rrs). An IATF (International Automotive Task Force) recognized certification body.

c. Services: Scope of accreditation includes: mining; quarrying; food; beverages; textiles; wood; pulp; paper; publishing; coke; petroleum; chemicals; fibers; rubber; plastics, nonmetallic minerals; metals; machinery; equipment; electrical products; optics; shipbuilding; other transport equipment; construction; wholesale and retail trade; transportation; storage; communication; information technology; engineering and other professional services. Encompasses SIC 372, 376, Major Group 60, 61, 62, $63,64,65,67$, and Major Group 27. Additional offices in Mexico, Brazil and Singapore and in the United States in Troy, MI and Berea, OH. Member of IAAR (Independent Association of Accredited Registrars). Uses IRCA (International Register of Certificated Auditors)/RAB-certified assessors. Can also audit to AS9100 and the TE Supplement.

2) Advanced Waste Management Systems, Inc. (AWMS)

6430 Hixson Pike or P.O. Box 100

Hixson, TN $37343 \quad$ Hixson, TN 37343

Phone: (423) 843-2206 (Contact: Richard A. Ellis/James Mullican)

Fax: (423) 843-2310

E-Mail: mail@awm.net

URL: www.awm.net

Other Information:

a. Accredited by: ANSI-RAB for ISO 14000 .

b. Other Program Recognition: Scope of accreditation is unlimited. One of the first five registrar companies accredited under the ANSI-RAB NAP for ISO 14000.

c. Services: Experienced in defense industries, nuclear waste storage and chemical industries. 
3) AEA Quality Advantage Corporation (AEA)

15 Myers Corners Road

Suite 1-S

Wappingers Falls, NY 12590

Phone: (845) 298-0032 (Contact: Nirmal S. Sandhu)

Fax: (845) 298-1253

E-Mail: aea@aeaquality.com

URL: www.aeaquality.com

Other Information:

a. Accredited by: RvA (Netherlands). Pursuing accreditation to EN (European Norm) 46000. Also, pursuing AS9100 and TL 9000 accreditation.

b. Other Program Recognition: Pursuing QS-9000 qualified registrar status by Ford/DaimlerChrysler/GM.

c. Services: Scope of accreditation includes: rubber; rubber products; plastic products; electrical equipment; optics; optical equipment; electrical products; pharmaceuticals. Uses IQA (Institute of Quality Assurance)/IRCA-certified assessors. Maintains other offices in Mexico, India and in the U.S. in Morgan Hills, CA and Houston, TX.

4) AFAQ-ASCERT (French Association for Quality Assurance) International, Inc. (AAI) 2500 West Higgins Road, Suite 1145

Hoffman Estates, IL 60195

Phone: 1-800-241-3412; (847) 755-9125 (Contact: Jose Mayer)

Fax: (847) 755-9130

E-Mail: jose.mayer@afaq.org

URL: http://www.afaq.fr

OR

50 Fullerton Court, Suite 202

Sacramento, CA 95825

Phone: (888) 476-8303 (Contact: Michael Bonawitz)

Fax: (916) 920-7028

E-Mail: aes safety@compuserve.com

URL: http://www.afaq.fr

OR

$105431^{\text {st }}$ Street, NW, Suite 320

Washington, DC 20007

Phone: (202) 338-4365 (Contact: Frederic Sevin);

Also (847) 755-9125 (IL); (916) 920-7028 (CA)

Fax: (202) 337-3709; also (847) 755-9130; (916) 920-7028

E-Mail: frederic.sevin@afaq.org

URL: www.afaq.fr

Other Information: 
a. Accredited by: Accredited by COFRAC (French Accreditation Committee) (France) and TGA/DAR (Germany). ANSI-RAB NAP QMS accreditation has been suspended.

b. Other Program Recognition: With over 11,000 certificates issued in more than 40 countries, AFAQ is the world's fifth-ranking management system registration body. QS-9000 qualified registrar by Ford/DaimlerChrysler/GM. An IATFrecognized certification body.

c. Services: Member of IAAR. AFAQ-ASCERT International Inc. is a subsidiary of AFAQ, which has issued over 11,000 quality management certificates. AFAQASCERT International, Inc. has a national and international network of $650 \mathrm{RAB}$, IRCA and/or IQA certified auditors. AFAQ-ASCERT International network covers the entire world with representation offices. AFAQ-ASCERT provides International Certificates with automatic recognition around the globe. Through an extensive network of certified audit ors, AFAQ-ASCERT provides comprehensive registration services in ISO 9000, QS-9000 and ISO 14000; Industrial, Agro-biological and Agro-food product certifications; process certification; certification of services; and certification of personnel. Scope of accreditation includes: AFAQ-ASCERT International covers all types of industries in 39 EAC (Economic Activity Code) scopes. Also, AFAQ-ASCERT International registration certificates are valid for three years. Surveillance audits are conducted annually. Additional certification services for CE (Conformite Europeene) Marking are available for companies exporting products or equipment to Europe. Founding member of IQNET. Member of IAAR.

5) AIB Vincotte USA

6161 Savoy Lane, Suite 1128

Houston, TX 77036

Phone: (407) 761-3384 (Contact: Vernon Portell)

Fax: (407) 452-9171)

E-Mail: vportell@aib-vincotte.com

URL: www.aib-vincotte.com

Other Information:

a. Accredited by: Finalizing ANSI-RAB accreditation for ISO 90001 and ISO 14000.

b. Other Program Recognition: None.

c. Services: Scope of accreditation includes: food and kindred products; paper and allied products; chemicals and allied products; rubber and plastics; food products and packaging; machinery; public warehousing and storage; groceries and related products; farm-produce raw materials; beer, wine and distilled alcoholic beverages; nondurable goods; food stores; pest control services; and cleaning/maintenance services. Caters to food and food-related industry companies only. 
6) Amador Product Service (See TUV Management Services entry below.)

7) American Global Standards (AGS) [formerly Davy Scott Registrars, Inc.]

300 Esplanade Dr., Ste. 1120

Oxnard, CA 93030

Phone: (805) 983-8200 (Contact: Gary Martel)

Fax: (805) 981-1034

E-Mail: admin@americanglobalstandards.com

URL: www.americanglobalstandards.com

Other Information:

a. Accredited by: ANSI-RAB for ISO 9000 and ISO 14000.

b. Other Program Recognition: None.

c. Services: Conducts QMS and EMS registrations. AGS was formerly known as Davy Scott Registrars, Inc. The registrar moved its offices to central California and changed its name in September 2000. AGS maintains its original auditing staff and has added new staff in California. ANSI-RAB approval of the name change was granted as of April 2001.

8) American Institute of Quality Registrars (AIQR)

15604 Farmington Road

Livonia, MI 48154 -2852

Phone: (734) 421-6413 (Contact: Michael Morse)

Fax: (734) 421-0353

E-Mail: mmorse@,aiqusa.com

URL: none reported

Other Information:

a. Accredited by: ANSI-RAB for ISO 9000.

b. Other Program Recognition: QS-9000 qualified registrar by Ford/DaimlerChrysler/GM.

c. Services: Contact AIQR directly for details on ISO 9000, ISO 14000 and TE Supplement services.

9) AGA Quality (See QMI entries.)

10) American Petroleum Institute Quality Registrar (APIQR)

1220 L Street, N.W.

Washington, DC 20005

Phone: (202) 682-8522 (Contact: Gerardo Uria)

Fax: (202) 682-8070

E-Mail: uriag@api.org 
URL: http://www.api.org

Other Information:

a. Accredited by: Accredited by ANSI RAB for ISO 9000. Has applied for ANSIRAB accreditation for ISO 14000.

b. Other Program Recognition: None.

c. Services: Above accreditation is being sought for the following major groups under SIC codes: Major Groups 28, 32, 33, 34, 35, 37 and 87. The APIQR registers suppliers to ISO 9001, but specializes in (1) the Dual Registration in API (American Petroleum Institute) Specification Q1/ISO 9001 or API Standard 1512/ISO 9001 of suppliers' quality systems already licensed in API's Monogram Program accredited by API's Petroleum Test Laboratory Accreditation Program (PTLAP) and (2) offering ISO 9001 registrations to those companies interested in petroleum industry-specific ISO re zistration. For the past 3 years, API Monogram licensees have had the opportunity to obtain ISO 9000 registration in conjunction with their Monogram product certification program application or renewal. Through the APIQR ISO 9000 Registration Program, companies may apply for ISO 9000 registration, API Monogram licensing, or both together under a newly integrated Dual Registration service. SIC codes are 1389, 1629, 2899, $30,324,329,331,339,34,353,356,359,3625,3731$ and 873 . Is the sole provider of API Monogram Program for Oil \& Gas Industry licensing and APIQR Dual Registration (API \& ISO 9000 combined). Q1 Registration.

11) American Quality Assessors (AQA)

1107 Belleview Avenue

Columbia, SC 29201

Phone: (803) 779-8150 (Contact: Patricia Pardue)

Fax: (803) 779-8109

E-Mail: patricia@aqausa.com

URL: www.aqausa.com

Other Information:

a. Accredited by: ANSI-RAB for ISO 9000 and ISO 14000. Also accredited by RvA (The Netherlands).

b. Other Program Recognition: QS-9000 and TE Supplement to QS-9000 qualified registrar by Ford/DaimlerChrysler/GM. An IATF-recognized certification body.

c. Services: Scope of accreditation includes: accounting, auditing, bookkeeping; educational services; electronic and other electric equipment (including computer and office equipment); fabricated metal products; furniture and fixtures; industrial machinery and equipment; management and public relations; miscellaneous manufacturing industries; noncommercial research organizations; paper and allied products; plastic products; primary metal industries; printing and publishing; rubber and miscellaneous; stone, clay and glass products; testing laboratories; textile mill products; wholesale trade-durable and nondurable goods. Also 
approved for the following SIC codes: \# 284, 382, 384, 385, 386 and 387.

Member of IAAR. AQA offers assessment and registration to the requirements of ISO 9000 2000, QS-9000, ISO TS (Technical Specification) 16949 and AS9100, ISO 14001 and the TE Supplement to QS-9000.

12) ASME, International

Three Park Avenue

New York, NY 10016-5990

Phone: (212) 591-8590 (Contact: David Wizda)

Fax: (212) 591-7674

E-Mail: wizdad@asme.org

URL: www.asme.org

Other Information:

a. Accredited by: ANSI-RAB for ISO 9000 and RvA (Netherlands).

b. Other Program Recognition: ASME's accreditation of manufacturers serves as a means of meeting a number of federal, state and local regulations.

c. Services: The registration program covers suppliers of mechanical equipment and related materials, items and services in the industries and sectors associated with the art, science and practice of mechanical engineering. Scope of accreditation includes: basic metals and fabricated metal products; machinery and equipment; engineering services and reinforced thermoset-plastic vessels.

13) American Systems Registrar (ASR)

4550 Cascade Road, SE, Suite 104

Grand Rapids, MI 49546

Phone: (888) 891-9002 (Richelle Kinzie)

Fax: (616) 942-6409

E-Mail: info@asrworldwide.com

URL: www.asr.9000.net

Other Information:

a. Accredited by: ANSI-RAB for ISO 9000 and ISO 14000.

b. Other Program Recognition: QS-9000 qualified registrar by Ford/DaimlerChrysler/GM.

c. Services: Serves the manufacturing and service industry. Provides ISO 9000 quotes within 24 hours. No hidden costs. Also conducts registration transfers. Conducts ISO 14000 registrations. Issues ISO 9001: 2000 certificates. Present ISO 9001/2/3:1994 certificates will be upgraded.

14) AOQC Moody International, Inc. - United States

24900 Pitkin Rd., Ste. 200 
The Woodlands, Texas 77386

Phone: (281) 367-8764 (Contact: Thomas Harris)

Fax: (281) 367-3496

E-Mail: tomh@moodyint.com

URL: http://www.aoqcmoody.com

Other Information:

a. Accredited by: ANSI-RAB for ISO 9000 . Home office accredited by UKAS (United Kingdom Accreditation Service) (U.K.) and TGA (Germany).

Accredited through AOQC Moody International Ltd. in the United Kingdom. SCC accredited through AOQC Moody International Ltd. in Canada. Also, TWI (The Welding Institute) (U.K.) for EN 729/ISO 3834. Accredited by COFRAC through AOQC Moody International in France. MAC accredited through AOQC Moody International in various wor' 1 wide network offices.

b. Other Program Recognition: QS-9000 qualified registrar by SCC (Standards Council of Canada) through Canadian sister company and TGA.

c. Services: Scope of accreditation includes boilers $\&$ pressure vessels; chemical machinery; compressors and fluid power equipment; construction industry equipment; cranes and lifting equipment; electrical equipment installation; electrical instruments and control systems; electrical equipment for motor vehicles; foundries; furnaces and kilns/iron working; metal fabrication and machining; metal furniture; paint and varnish production; plant recessing equipment; printed circuit boards; process engineering; pumps; structural steel; chartered accountants; cleaning services; distribution of fuels and industrial materials; distribution of machinery and industrial equipment; distribution of timber and building materials; freight forwarders; facility and equipment leasing; interior design for shops and offices; printing and publishing of literature and stationery; professional and technical services; recruitment agencies; stocking distributors; storage and warehousing; training establishments. Has offices in Tucson, AZ; Medina, OH; Charlotte, NC; and Redmond, WA. Maintains other offices in Abu Dhabi, Japan, Canada, Indonesia, China (People's Republic of), Italy, England, Malaysia, Germany, Kingdom of Saudi Arabia, The Netherlands and Singapore. Offers assessment to AS9100, ISO 14000, VDA (Verband der Automobilindustrie) 6.1, ISO/TS (Technical Specification) 16949, ISO/IEC 17025 and OSHAS (Occupational, Safety and Health Administration Standard) 18001.

15) AOQC Moody International Registration Ltd. (AOQC) - Canada

57 Simcoe St., South, Ste. $2 \mathrm{H}$

Oshawa, Ontario L1H 4G4 Canada

Phone: (905) 433-2955 (Contact: David Bright/George Harwood/Stanley

Harris/JoanneSmith)

Fax: (905) 432-9308

E-Mail: aogc osh@compuserve.com

URL: www.moodycanada.com 
Other Information:

a. Accredited by: ANSI-RAB for ISO 9000 for U.S. location. UKAS (U.K.), TGA (Germany), SINCERT (Italian National System for the Accreditation of Certification Bodies) (Italy), COFRAC (France), SCC (Canada) and MAC.

b. Other Program Recognition: none reported

c. Services: Scope of accreditation includes: Accredited by the SCC for the following SIC codes - 12, 14, 17, 18, 19, 21, 25, 31, 33 \& 34. Accreditation pending for SIC codes 20 \& 29.

16) AQSR International Inc.

3025 Boardwalk Dr., Ste. 120

Ann Arbor, MI 48108

Phone: (888) 866-5666 x303 (Contact: Brad Kitchen)

Fax: (905) 624-7213

E-Mail: bkitchen@aqsr.com

URL: www.aqsr.com

Other Information:

a. Accredited by: ANSI-RAB for ISO 9000 and ISO 14000.

b. Other Program Recognition: QS-9000 qualified registrar by Ford/DaimlerChrysler/GM. An IATF recognized certification body.

c. Services: Scope of accreditation includes: rubber and plastics; leather tanning and finishing; leather goods; primary metal industries; fabricated metal products; industrial machinery and equipment; motor vehicle parts and accessories; and adhesives and sealants; lubricating oils and greases; and miscellaneous manufacturing industries. AQSR International Inc. complies with EN 45012 for the registration of quality management systems. Conducts assessments to QS 9000 and the TE Supplement to QS-9000. Conducts assessments to AS9100, TL9000, ISO/TS 16949, ISO/IEC 17025 and VDA 6.1.

17) AV Qualite (AVQ) (See Det Norske Veritas Certification, Inc./DNV entry below.)

18) BQR Ltd.-BestCERT Quality Registrars Ltd. (BQR)

[formerly Barbieri Quality Registrars, Inc.]

55 Lake Street, Suite 240

Gardner, MA 01440

Phone: (978) 630-3993 (Contact: Sandy Tokola)

Fax: (978) 630-3909

E-Mail: bqriso@aol.com

URL: www.bestcert.org

Other Information: 
a. Accredited by: ANSI-RAB for ISO 9000. Has applied for ANSI-RAB accreditation for ISO 14000.

b. Other Program Recognition: QS-9000 qualified registrar by Ford/DaimlerChrysler/GM.

c. Services: IAF (International Accreditation Forum) Scope Categories include: 1) Food Products, Beverages and Tobacco - except manufacture of tobacco products; 2) Textiles and Textile Products; 3) Pulp, Paper and Paper Products; 4) Publishing Companies; 5) Printing Companies; 6) Rubber and Plastic Products; 7) Nonmetallic Mineral Products; 8) Concrete, Cement, Lime, Plaster, etc.; 9) Basic Metals and Fabricated Metal Products - except manufacture of basic processing of iron and steel and production of ferro-alloys and casting of metals; 10) Machinery and Equipment; 11) Electrical and Optical Equipment; 12) Aerospace; 13) Manufacture not elsewhere classified; 14) Construction; 15) Wholesale and Retail Trade, Repair of Motor Vehicles, Motorcycles and Personal/Household Goods - except maintenance and repair of motor vehicles and repair of personal/household goods; 16) Transport, Storage and Communication; 17) Engineering Services; 18) Other Services; 19) Public Administration; 20) Education; 21) Health and Social Work - except human health activities; 22) Other Social Services and 23) Medical Devices. Surveillance audits can be arranged for either 6 month or 12-month intervals. Registration certificates are valid for three years from the date of registration. $B Q R$, Limited has offered quality system registration for $21 / 2$ years. Owned and operated by experienced quality professionals. Auditors have actual industry experience and have audited hundreds of companies in many industries. Currently has offices in the U.S., Taiwan, People's Republic of China and Republic of Korea. Conducts TL (Telecommunications) 9000 assessments. Accredited by ANSI-RAB to run Lead Auditor course for 36 hours. Also conducts AS9100 registrations.

19) Bellcore Quality Registration Services (See Telcordia Quality Registration entry below.)

20) BSI, Inc. (BSI, INC)

12110 Sunset Hills Road, Suite 140

Reston, VA 20190-3231

Phone: (703) 464-1931 (Contact: Tom Shelley)

Fax: (703) 437-9001

E-Mail: tom.shelley@bsiamericas.com

URL: www.bsiamericas.com

Other Information:

a. Accredited by: Parent company is accredited by UKAS (U.K.), RvA (Netherlands) and INMETRO (Brazil). BSI, Inc. is covered by both UKAS and RvA accreditations. Accredited for ISO 14001 by UKAS (U.K.). Has ANSI-RAB accreditation for ISO 9000 and ISO 14000. Note: A subsidiary of the British 
Standards Institution incorporated by Royal Charter in the United Kingdom. Also accredited by the UKAS (UK) under the TickIT certification scheme for software development.

b. Other Program Recognition: Has operational MOUs (Memoranda of Understanding) with Underwriters Laboratories (USA), QMI (Quality Management Institute) (Canada), JMI (Japanese Management Institute) (Japan), AS (Standards Australia) (Australia), SSI (Singapore Standards Institute) (Singapore), STQC (Standards Testing and Quality Control) (Thailand), BICQ (Taiwanese Institute of Quality Control) (Taiwan) and HKQAA (Hong Kong Quality Assurance Association) (People's Republic of China). Parent company in U.K. is QS-9000 qualified registrar by Ford/DaimlerChrysler/GM. Also recognized for EMAS (European-Eco-Management and Audit Scheme).

c. Services: Member of IQNET (International Quality Certification Network) and IAAR. Offices in Canyon Lake, CA; Houston, TX; Detroit, MI; and Chatham, NJ. Issued over 33,000 certificates of registration in over 74 countries worldwide. BSI's registration services cover virtually all industry and commercial Standard Industrial Classification (SIC) codes and all sizes of organizations from small and medium-sized companies to very large multi-national corporations. Conducts AS9100 for Aerospace, TL 9000 and BS (British Standard) 7799 (Information Security Management). Also, TE Supplement and Alternative Method. Assessment expertise includes ISO/TS 16949, VDA 6.1, ISO/IEC Guide 25, ISO 17025 , OSHAS 18001 (BS 8800) and CE marking. BSI is a notified body.

21) Bureau de normalisation du Quebec - Systems registration (BNQ-SR) (A Division of the Centre de recherche industrielle du Quebec or CRIQ)

8475 Christophe-Colomb Avenue

Montreal, Quebec H2M 2N9

Phone: (514) 383-3239

Fax: (514) 383-3260

E-Mail: bnqmla@prolognet.qc.ca

URL: http://www.criq.qc.ca/bnq/

OR

333 rue Franquet

Sainte-Foy, Quebec G1P 4C7

Phone: (418) 652-2296; 1-888-267-1476 (Contact: Sylvie Lavoie)

Fax: (418) 652-2221

E-Mail: BNQES@,criq.qc.ca

URL: http://www.criq.qc.ca/bnq/

Other Information:

a. Accredited by: SCC (Canada).

b. Other Program Recognition: None listed.

c. Services: Scope of accreditation: agricultural production and services; forestry; fishing; hunting and trapping; mining; construction; food and kindred products; tobacco products; textile products; lumber and wood products; furniture and 
fixtures; paper and allied products; printing, chemicals and allied products; petroleum; rubber; leather; stone; primary metal industries; industrial machinery; electronic and other electric equipment; transportation; motor freight transportation; postal service; water transportation; communications; electric, gas and sanitary services; wholesale trade - nondurable and durable goods; general merchandise stores; automotive dealers; apparels and accessory stores; retail; nondepository credit institutions; real estate; holding and other investment offices; business services; automotive repair; motion pictures; amusement and recreation services; health, legal and educational services; engineering and accounting; research and Management services. BNQ's registration is valid for three years. Surveillance audits are conducted every 12 months from the date of registration or more often, if required by the clients or specific agreements. Other offices are in Ottawa, Quebec and Edmundston. Offers ISO 9001, 9002, 9003, 14001, ISO/IEC Guide 25/ISO/IEC 17025 and HAC CP (Hazard Analysis Critical Control Point)/9000 assessments. Offers quality systems evaluation according to ISO 9001: 2000. Also, as SCC's partner, BNQ offers laboratory accreditation to ISO 17025. BNQ-Registration Systems is a division of the Center for Industrial Research of Quebec (CRIQ). BNQ is a Canadian pioneer in registering quality systems to ISO standards and has over 30 years of experience with standards.

22) Bureau Veritas Quality International (N.A.) Inc. (BVQI)

515 West $5^{\text {th }}$ Street

Jamestown, NY 14701

Phone: (716) 487-9002 x114 (Contact: Don Burdick)

Fax: (716) 664-7588

E-Mail: dburdick@bqina.com

URL: www.bvqina.com

Other Information:

a. Accredited by: ANSI-RAB for ISO 9000 and ISO 14000 and by SCC (Canada). Parent and sister companies are accredited by: UKAS (U.K.), RvA (Netherlands), BELCERT (Belgian Accreditation System) (Belgium) and SWEDAC (Swedish Board for Accreditation and Conformity Assessment) (Sweden), Swiss Accreditation Service (SAS) (Switzerland), COFRAC (France), DAR (Germany), SINCERT (Italy), DANAK (Dansk Akkreditering) (Denmark), JAZ-ANZ (Joint Accreditation System of Australia and New Zealand) (Australia-New Zealand), INMETRO (Brazil) and ENAC (Entidad Nacional de Acreditacion) (Spain). Accredited by UKAS (U.K.) under the TickIT certification scheme for software development. Accredited registrar for ISO 14000 with accreditations available under the UKAS, RvA, DANAK, SWEDAC and SAS.

b. Other Program Recognition: QS-9000 qualified registrar by Ford/DaimlerChrysler/GM. An IATF-recognized certification body.

c. Services: Member of IAAR. Has 7 regional offices within the USA in Colorado; Providence, RI; Fort Mill, SC; Plano, TX; West Bloomington, MN; and 
Jamestown, NY. BVQI is a notified body in accordance with the EMC Medical Devices Directive (93/42/EEC) and Active Implantable Medical Devices Directive (90/385/EEC). Offers assessments to SA 8000 and AS9100. Has offices in 45 countries with more than 22,000 clients and more than 1,400 small to large companies in North America have chosen BVQI. Offers HAACP, SFI (Six Figure Income), SafetyCert, Codes of Conduct, TE Supplement, TL 9000, ISO/TS 16949 assessments, Alternative Method and AS9100. Recently acquired Kemper Registrar Services, Inc.

23) Calidad Mexicana Certificada, A.C. (CALMECAC) Jose Vasconcelos No. 83 Col. San Miguel Chapultepec Mexico, D.F.,C.P. 11850

Phone: $52555530571 \times 255$ or 351 (Contact: Jaime Acosta)

Fax: 5252116702

E-Mail: rpublicas@calmecac.com.mx

URL: http://www.calmecac.com.mx

Other Information:

a. Accredited by: Accredited by Entidad Mexicana de Acreditacion (EMA). Has ANSI-RAB accreditation for ISO 9000 and ISO 14000. Pursuing KBA (Kraftfahrt-Bundesamt) accreditation for VDA 6.1.

b. Other Program Recognition: This is the first quality system registrar accredited under the Mexican National Accreditation and Certification System.

c. Services: Also has attained certification of quality system auditors in Mexico under ISO 10011-2/NMX-CC (Guideline for Selecting Quality Auditors/Official Mexican Standard) 8. Certification officially recognized by Norma Oficial Mexicana (NOM). Can certify quality management systems to QS-9000. Also, accredited in labor personnel competence (Consejo de Normalizacion y Certificacion de Competencia Laboral - CONOCER). Offers assessments to NOM-TUR (Official Mexican Standard/Technical Specifications) from 1 to 7 , NOM-004-SCFI (Commercial Information on Labels for Textiles, Clothing and Accessories), NOM-024-SCFI, NOM-050-SCFI, NOM-051-SCFI, NOM-020SCFI, NOM-015-SCFI, NOM-141-SSA1, NOM-142-SSA1 (Goods and Services, Labels for Prepackaged Perfumes and Beauty Products) and Normas de Competencia Laboral.

24) Canadian General Standards Board (CGSB)

Place du Portage, Phase III, 6B1

Hull, Quebec K1A 1 G6

Phone: (819) 956-0425 (Contact: Desmond Gray)

Fax: (819) 956-5644

E-Mail: Desmond.G.Gray@pwgsc.gc.ca

URL: http://www.pwgsc.gc.ca/cgsb 
Other Information:

a. Accredited by: SCC (Canada).

b. Other Program Recognition: Has MOUs with UL (USA), NSAI (National Standards Authority of Ireland) (Ireland) and with SIRIM (Scientific and Industrial Research Institute of Malaysia) (Malaysia).

c. Services: Scope of accreditation includes: SIC (Standard Industrial Classification) codes \# 4; 6; 7; 9;10;12;13;14;15;17, excluding manufacture of basic precious and non-ferrous metals; 18 , excluding manufacture of weapons and ammunition and manufacture of domestic appliances n.e.c.; 19, excluding manufacture of television and radio receivers, sound or video recording or reproducing apparatus and associated goods, manufacture of medical and surgical equipment and orthopedic appliances and manufacture of watches and clocks; $21 ; 22 ; 23 ; 24 ; 28$, excluding renting of constructio.x or demolition equipment with operator; $29 ; 33$, excluding data processing and data base activities; 34 ; and 36 . Also has ISO 14001 accreditation through SCC (Canada). Conducts assessments to AS9100. Also, ISO 13485 (medical devices) in process.

25) Certech Registration Inc.

4623 Sherwoodtowne Boulevard, Suite 300

Mississauga, ON L4Z 1 Y5 Canada

Phone: (905) 273-6338 (Contact: Frank Strohmeier)

Fax: (905) 273-3378

E-Mail: frank@,certech.org

URL: none reported

Other Information:

a. Accredited by: ANSI-RAB for ISO 9001.

b. Other Program Recognition: None reported

c. Services: Scope of accreditation includes: contact registrar directly as above for specific details.

26) CRS Registrars, Inc. (CRS)

135 Chesterfield, Suite 201

Maumee, $\mathrm{OH} 43537$

Phone: (419) $891-7333$ x26 (Contact: Carl Blazik)

Fax: (419) 861-1696

E-Mail: cfblazik@crsregistrars.com

URL: www.crsregistrars.com

Other Information:

a. Accredited by: ANSI-RAB for ISO 9001 and 14000 . 
b. Other Program Recognition: QS-9000 qualified registrar by Ford/DaimlerChrysler/GM.

c. Services: Scope of accreditation includes: general building contractor; special trade contractors; primary metal industries; industrial machinery and equipment; transportation equipment; communications; wholesale trade; miscellaneous repair; engineering management; environmental quality; heavy construction; furniture and fixtures; fabricated metal; electronic, electrical instruments; electric, gas, sanitary; business services; services, N.E.C.; administration of economic programs. Also ARD (Aerospace Research and Development) 9000. As of August 4, 1997 CRS Registrars' scope of accreditation was broadened to include all chemicals and allied products (SIC 28), excluding drugs (SIC 283), all petroleum and coal products (SIC 29), all rubber and miscellaneous plastic products (SIC 30), all stone, clay and glass products (SIC 32). Offers registration of companies to ISO 9000 and QS-9000 in the following SIC codes: 25, 28-29, $48-50,73,76,82,87,89,95$ and 96. Member of IAAR. Conducts assessments against TE Supplement to QS-9000 and AS9100. ISO 14000 accredited through ANSI-RAB. Conducts assessments against ISO Guide 25/ISO17025. Planning seminars to address changes to ISO 9000 . Also conducting training for auditors and staff on ISO 9000:2000, VDA 6.1 and ISO 17025.

27) Davy Scott Registrars, Inc. (DSR) (See American Global Standards/AGS entry.)

28) Defense Supply Center, Columbus (DSCC-VQ)

P.O. Box 3990

Columbus, $\mathrm{OH} 43216-5000$

Phone: (614) 692-0679 (Contact: Darrell Hill)

Fax: (614) 692-6942

E-Mail: Louie_Hill@dscc.dla.mil

URL: http://www.dscccols.com/offices/Sourcing_and_Qualification

Other Information:

a. Accredited by: DSCC's is recognized the U.S. Department of Defense (DOD) as the U.S. National Qualifying Activity for electronic components. Registrations issued by DSCC have readily been accepted internationally by customers of Qualified Products List/Qualified Manufacturers List (QPL/QML) manufacturers. If a QPL/QML manufacturer requests an accredited registration, DSCC has established Memoranda of Understanding (MOU) with accredited registrars who accept DSCC assessments as part of their registration scheme.

b. Other Program Recognition: DSCC currently has MOUs with NSF International, EAGLE Registrations, Inc. and KEMA Registered Quality.

c. Services: Program is only open to manufacturers in the military QPL/QML (Qualified Product List/Qualified Manufacturers List) program. 
29) Deloitte \& Touche Quality Registrar Inc. (D\&T QRI)

150 Ouellette Place, Suite 200

Windsor, Ontario N8X 1L9 Canada

Phone: 1-888-258-2240 x714(Contact: Dan DeMartin)

Fax: (519) 967-0324

E-Mail: dademartin@deloitte.ca

URL: www.deloitte.ca

Other Information:

a. Accredited by: ANSI-RAB for ISO 9001 and ISO 14000 .

b. Other Program Recognition: QS-9000 qualified registrar by Ford/DaimlerChrysler/GM. Also, conducts assessment to QS-9000 TE Supplement accreditation.

c. Services: Scope of accreditation includes: from SIC 01 (Agricultural Production Crops) to SIC 92 (Justice, Public Order and Safety). ISO 14000 Environmental Management Systems registration services accredited through sister company in Europe. Offers assessments to AS9100. Member of IAAR. Offers assessment to ISO 9001:2000.

30) Det Norske Veritas Certifications, Inc. (DNV)

16340 Park Ten Place, Suite 100

Houston, TX 77084

Phone: (281) 721-6818 (Contact: Yehuda Dror)

Fax: (281) 721-6903

E-Mail: yehuda.dror@dnv.com

URL: www.dnvcert.com

Other Information:

a. Accredited by: ANSI-RAB for ISO 9001 and ISO 14000 . Parent/affiliate DNV companies are accredited by: UKAS (U.K.), SINCERT (Italy), INMETRO (Brazil), RvA (The Netherlands), BELCERT (Belgium), ENAC (Spain), SWEDAC (Sweden), DANAK (Denmark), BMwA (Bundesministerium Akkreditierung) (Austria/Republik Oesterreich/Europa), NA (Norway), FINAS (Finnish Accreditation Service) (Finland), KSA (Korean Standards Association) (Republic of Korea), TGA/DAR (Germany), SAS (Switzerland), COFRAC (France), JAS-ANZ (Australia-New Zealand/Pacific Rim area/region), JAB (Japan), IPQ (Instituto Paulista da Qualidade (Portuguese/Sao Paulo, Brazil), NABCB (Quality Council of India) (India), OAA (Organismo Argentino de Acreditacion) (Argentina) and HKCAS (Hong Kong Certification Body Accreditation Scheme) (Hong Kong, People's Republic of China).

b. Other Program Recognition: QS-9000 qualified registrar by Ford/DaimlerChrysler/GM. An IATF-recognized certification body.

c. Services: Operates in Houston, TX (Headquarters); River Edge, NJ; Long Beach, CA; Atlanta, GA; Detroit, MI; and Toronto, ON, Canada. Member of IAAR. 
Approved to issue AS9100 certificates of conformity. DNV is a Notified Body providing CE Mark Services for 12 different Directives including Medical Devices, Pressure Equipment and Machinery. Offers assessments to TL 9000. Recognized registrar for ISO/TS 16949, ISO 9001, SA (Social Accountability) 8000, ISO 14000 (EMS), EMAS, TickIT, BS 7799, VDA 6.1, AVSQ94, SCC, EN 46001/2, ISO 13485 and EN 729.

31) DLS Quality Technology Associates, Inc. (DLS)

100 Main St.

Camillus, NY 13031

Phone: (315) 672-3598 (Contact: Duane Dodge)

Fax: (315) 672-3596

E-Mail: dlsqual@aol.com

URL: none reported

Other Information:

a. Accredited by: ANSI-RAB for ISO 9001.

b. Other Program Recognition: QS-9000 qualified registrar by

Ford/DaimlerChrysler/GM. AS 9100 accreditation pending.

c. Services: Member of IAAR.

32) DQS, Inc. - Registration Services

German American Registrar for Management Systems, Inc.

3601 Algonquin Rd., Ste. 305

Rolling Meadows, IL 60008

Phone: (847) 797-1860 (Contact: Roger Davis)

Fax: (847) 797-1876

E-Mail: rdavis@dqsusa.com

URL: www.dqscertus.com

or www.dqs.de/

Other Information:

a. Accredited by: DAR/TGA (Germany). ANSI-RAB accredited for ISO 9001.

b. Other Program Information: QS-9000 qualified registrar by Ford/DaimlerChrysler/GM.

c. Services: Registrar for ISO 9000, ISO 14001, QS-9000, VDA 6.1 and AS9100. Serves all industry sectors. Internationally recognized as member of IQNET. Has over 600 highly qualified auditors with management experience expertise. Registered 8,500 + global companies. Maintains offices in the U.S., Mexico, Germany, Eastern Europe, Asia, Brazil and South Africa. Provides registration services to the ISO 9001:2000. 
33) EAGLE Registrations, Inc.

2242 West Schantz Avenue

Dayton, OH 45409

Phone: (937) 293-2000 (Contact: Chris Shillito)

Fax: (937) 293-0220

E-Mail: chris.shillito@eagleregistrations.com

URL: www.eagleregistrations.com

Other Information:

a. Accredited by: RvA (Netherlands). ANSI-RAB for ISO 9001.

b. Other Program Recognition: QS-9000 qualified registrar by Ford/DaimlerChrysler/GM. Many EAGLE auditors are ALAG-approved QS-9000 automotive assessors.

c. Services: Scope of accreditation includes: aerospace; automotive/transportation equipment (QS-9000); chemicals, chemical products and fibers; concrete, cement, lime, plaster, etc; construction; electronic, electrical, computer and optical equipment; engineering and other services (ISO/IEC Guide 25); food products and beverages; (HACCP); metals and fabricated metal products; machinery; tooling and equipment (TE Supplement); pharmaceuticals; pulp, paper and paper products; printing; publishing; rubber and plastic products; textile and textile products; transportation, storage and communications; and wholesale/retail. Also, complies with EN 45012 and ISO 10011. Uses IRCA/IQA-certified or RABapproved auditors. Also, notified body for CE Marking for European Union (EU). ISO 14000 accreditation. Offers assessments to TE Supplement. EAGLE also offers accredited ISO 9000 and ISO 14000 training classes. Note: EAGLE's registration contract and certificate are open-ended and may be canceled at any time by consensus of any EAGLE's customer. Surveillance audits are conducted every 6 months to 1 year. Triennial re-registration audits are not required as part of the EAGLE registration system. Conducts assessments to ISO 9000, OS (Operating Systems), AS, TE Supplement, ISO/IEC Guide 25, AS9100, and is a General Electric Aircraft Engines (GEAE) approved AS9100 registrar. Conducts assessment to TL 9000 for telecommunications. Member of IAAR. Conducts assessments to ISO/TS 16949. Sister company, ACLASS, is ISO/IEC 17025 accreditation body.

34) EAQA USA Registrars, Inc.

15475 Chemical Lane

Huntington Beach, CA 92649

Phone: (714) 373-3773 (Contact: Tom Haney)

Fax: (714) 373-3775

E-Mail: info@eaqausa.com

URL: http://www.eaqausa.com 
Other Information:

a. Accredited by: UKAS (U.K.). ANSI-RAB for ISO 9001.

b. Other Program Recognition: QS-9000 qualified registrar by

Ford/DaimlerChrysler/GM. Also accredited under the ISO 9000-3

Software/TickIT (U.K.) Scheme.

c. Services: Offers registration for ISO $9000 / \mathrm{QS}-9000$ and ISO 14000

Environmental Management. Conducts assessments to AS9100 and TL 9000. TS 16949 certification is available through affiliation with AFAQ/ASCERT.

Worldwide certification is provided through EAQA offices located in the United

Kingdom, France, Switzerland, Abu Dhabi, South Africa, India, Malaysia,

Thailand, Indonesia, People's Republic of China, Republic of Korea, Australia,

Mexico, Costa Rica and Brazil. Also, has teamed with Quality Assurance

Services of North America (QASNA) to provide accredited training courses.

Maintains offices in Huntington Beach, CA; Los Angeles, CA; Gulfport, MS;

Nashville, TN; and McAllen, TX. More offices opening in Denver, CO; San

Francisco, CA; Washington, D.C.; and the Great Lakes region soon. U.K. contact: Electricity Association Quality Assurance Ltd (EAQA), Natasha Richards, 30 Hill Bank, London, SW1P 4RD England, phone: 0207963 5947, fax: 0207828 9237, e-mail: enquiries@eaqa.demon.co.uk. EAQA provides accredited ISO 9000 and ISO 14000 certification from offices across the United States and around the world.

35) Emaco Product Service (See TUV Management Services entry below.)

36) Entela, Inc. QSRD

2625 Buchanon, S.W.

Grand Rapids, MI 49548

Phone: (616) 222-7979 (Contact: Lisa Hemmer)

Fax: (616) 222-7999

E-Mail: 1hemmer@entela.com

URL: www.entela.com

Other Information:

a. Accredited by: RvA (Netherlands), ANSI-RAB for ISO 9001 and ISO 14001, and DAR (Germany) The RvA accreditation is specified to, for example, SIC code 42 (transportation and warehousing). See below.

b. Other Program Recognition: QS-9000 qualified registrar by

Ford/DaimlerChrysler/GM. IATF/IAOB recognized registrar for ISO/TS 16949.

c. Services: Assessors meet requirements of ISO 10011-2 and the IRCA/RAB lead assessor criteria. Has facilities in Taipei, Taiwan (Formosa). Scope of accreditation includes: textile mill products; textile products; wood and wood products; furniture and fixtures; pulp, paper and allied products; printing and publishing; chemicals, chemical products and fibers; rubber and plastic; stone, 
clay and glass; primary metals; fabricated metals; machinery and equipment; electrical and optical equipment; transportation (QS-9000); motor vehicles and equipment; railroad equipment; motorcycles, bicycles and parts; personal and household goods; miscellaneous transportation equipment; measuring and controlling devices; personal safety appliances; miscellaneous manufacturing; transportation and warehousing; wholesale trade - durable; wholesale trade nondurable; and engineering and management services. Member of IAAR. Offers assessment to ISO 14001 and TE Supplement. Building construction; construction - heavy, construction - special trade contractors group and Medical Devices. An IATF recognized certification body. Offers assessment to VDA 6.1. ISO/TS 16949. Member of IAOB (International Automotive Oversight Bureau). Exclusive partnership for registration services in Brazil, Germany and Republic of Korea. Comprehensive scope of accreditation with Assessors meet requirements of ISO 10011-2, IRCA/RAB lend assessor criteria and TL 9000.

37) Excalibur Registrations, Inc. (ERI)

20740 Ryan Rd., Ste. 100

Warren, MI 48091-2738

Phone: (586) 755-9100 (Contact: Robert Zanni)

Fax: (586) 755-9110

E-Mail: excalibur9000@earthlink.net

URL: www.excaliburregistrations.com

Other Information:

a. Accredited by: ANSI-RAB for ISO 9001. ANSI-RAB ISO 14000 (EMS) accreditation pending.

b. Other Program Recognition: QS-9000.

c. Services: Conducts quality compliance audits and ISO 9001 assessments. IAF codes: 14, 17, 18, 21, 22, 23, 24, 29, 30, 31, 34 and 35. Conducts ISO/TS 16949 assessments and assessments to TE Supplement and AS9100.

38) Factory Mutual Research Corp. (FMRC)

1151 Boston-Providence Turnpike

Norwood, MA 02081

Phone: (781) 255-4972 (Contact: John P. Hill)

Fax: (781) 762-9375

E-Mail: john.hill@fmglobal.com

URL: http://www.fmglobal.com

Other Information:

a. Accredited by: RvA (Netherlands). 
b. Other Program Recognition: Has MOU with International Quality Corporation (IQC) USA, Sira Certification Service (UKAS/UK-accredited registrar), Vouching Technical Inspection, Ltd. (VTI, Beijing, People's Republic of China) and UL of North America.

c. Services: All auditors are certified through IRCA. Scope of accreditation includes: textiles; pulp; paper; chemicals; petroleum; rubber; plastics; stone/glass/concrete; metals; industrial and computer equipment; electrical/electronic equipment; manufacturing; communications; durable goods; and the multiple areas/categories of personal/business/repair/engineering/accounting/research-related services. Certified FMRC auditors are located in offices throughout North America. Offers ISO 14000 registration services. Conducts assessments to AS9100 and TL 9000. Also conducts facility and procedures audits, which cover product certifications and quality management systems.

39) GBJD Registrars Ltd.

9251-8 Yonge Street, Suite 310

Richmond Hill, Ontario L4C 9T3 Canada

Phone: (905) 727-6980; 1-877-256-1967; (705) 526-3995 (Contact: R.F. Grayston)

Fax: (905) 727-1730; (705) 526-6113

E-Mail: rayman@solve.net

URL: none reported

Other Information:

a. Accredited by: Parent company is accredited by UKAS (U.K.).

b. Other Program Recognition: TickIT-accredited by UKAS for software. QS-9000 qualified registrar by Ford/DaimlerChrysler/GM.

c. Services: Lead assessors are certified by IRCA. GBJD certifies products for use in explosive atmospheres in the U.K. Also maintains office in the U.S. at P.O. Box 956, Orland Park, IL 60462; contact C. Jenrich at phone (708) 349-8342 and fax (708) 957-6968.

40) Global Registrars, Inc. (GRI)

4700 Clairton Boulevard

Pittsburgh, PA 15236

Phone: (412) 884-2290 (Contact: Elmer Bennett)

Fax: (412) 884-2268

E-Mail: bennette@globalregistrars.com

URL: http://www.globalregistrars.com

Other Information:

a. Accredited: ANSI-RAB for ISO 9001 and by RvA (Netherlands). 
b. Other Program Recognition: QS-9000 qualified registrar by Ford/DaimlerChrysler/GM.

c. Services: Scope of accreditation includes: mining; quarrying; construction; paper products; printing; chemicals; non-metallic minerals; metals; machinery; equipment; transportation; trade and engineering services. Member of IAAR.

41) HSB Registration Services (HSBRS)

595 East Swedesford Rd. or P.O. Box 61509

Wayne, PA $19086 \quad$ King of Prussia, PA 19406-0909

Phone: (484) 582-1419 (Contact: Janet Kowalski)

Fax: (484) 582-1802

E-Mail: janet_kowalski@hsbct.com

URL: www.hsbiso.com

Other Information:

a. Accredited by: ANSI-RAB for ISO 9001. RvA (Netherlands).

b. Other Program Recognition: QS-9000 qualified registrar by Ford/DaimlerChrysler/GM.

c. Services: Scope of accreditation ranges from general building contractors (SIC $15)$ to nondestructive examination (SIC 8734). Member of IAAR. Also, conducts assessments to ASME and NQA (National Quality Assurance) requirements.

42) International Approval Services, Inc. (IAS) [See QMI entry.]

8501 E. Pleasant Valley Rd.

Cleveland, $\mathrm{OH}$ 44131-5575

Phone: (216) 901-1911 (Contact: Jim Solich)

Fax: (216) 520-8967

E-Mail: jsolich@gmi.com

URL: www.qmi.com

Other Information:

a. Accredited by: SCC (Canada), RvA, (The Netherlands) and EMA (Mexico).

b. Other Program Recognition: QS-9000 qualified registrar by Ford/Daimler/Chrysler/GM.

c. Services: conducts assessments to ISO 14000. Also conducts assessments to AS9100, TL 9000, ISO/TS 16948, ISO/IEC 17025, ISO 13485, MS (Malaysian Standard)/ISO 9000 and TAPPI (Technical Association of the Pulp and Paper Industry) specifications.

43) Instituto Mexicano de Normalizacion y Certificacion, A.C. (IMNC) Manuel Maria Contreras No. 133 Piso 1, Col. San Rafael 
Cuauhtemoc C.P. 06470

Mexico Distrito Federal

Phone: (525) 5664750 (Contact: Joel Narvaez/Felipe Reyes)

Fax: (525) 5464546

E-Mail: imnc@inetcorp.net.mx

URL: none reported

Other Information:

a. Accredited by: Direccion General de Normas (DGN) under the Secretaria de Comercio y Fomento Industrial (SECOFI) and Entidad Mexicana Acreditacion (EMA) in Mexico.

b. Other Program Recognition: MOUs in development with QMI (Canada) and ASCERT (France).

c. Services: IMNC has registered companies in Mexico, USA and Canada. IMNC certification is useful in fulfilling some Mexican government requirements. Distributes the ISO 9000 and QS-9000 standard manuals in Spanish/en Espanol.

44) International Quality Certifications, S.A., DE C.V. (IQC)

Calle Joselillo No. 6-A

Despacho 908, Colonia El Parque, Naucalpan

Estado de Mexico C.P. 53390

Phone: 5255575023 (Contact: Fernando Adams Gallegos)

Fax: 5255579629

E-Mail: none reported

URL: none reported

Other Information:

a. Accredited by: ANSI-RAB for ISO 9001. Has applied for accreditation by ANSI-RAB's NAP for ISO 14000 EMS.

b. Other Program Recognition: none reported

c. Services: Not specified

45) International Management Systems, Inc. (IMS)

5420 Bay Center Drive, Suite 200

Tampa, FL 33609

Phone: (813) 639-9876 (Contact: Steve Pearson)

Fax: (813) 639-9875

E-Mail: Mriso9000@aol.com

URL: www.ims4iso.com

Other Information:

a. Accredited by: ANSI-RAB for ISO 9001.

b. Other Program Recognition: none reported 
c. Services: Provides in-house training for auditors and sales people towards the ISO 9001:2000 required changes. Will offer clients information on the transition plan during each surveillance audit.

46) International Quality Registrars Corp. (IQR)

1 Davis Avenue, Suite 101

Frederick, MD 21701

Phone: (301) 696-9740 (Contact: Tom Broderick)

Fax: (301) 696-9776

E-mail: iqrcorp@erols.com

URL: www.iqrcorp.com

Other Information:

a. Accredited by: Offering co-registration with Factory Mutual Research Corp.(FMRC/Norwood, MA) with RvA (Netherlands) accreditation.

b. Other Program Recognition: none reported.

c. Services: Offers assessments to ISO 9001:2000. Extensive experience in manufacturing, process and service industries.

47) International Quality System Registrars (IQSR)

7025 Tomken Road, Suite 271

Mississauga, Ontario L5S 1R6 Canada

Phone: (905) 565-0116 (Contact: Nick Budd)

Fax: (905) 565-0117

E-Mail: iqsr@iqsr.com

URL: http://www.iqsr.com

Other Information:

a. Accredited by: SCC (Canada) and by ANSI-RAB for ISO 9001.

b. Other Program Recognition: QS-9000 qualified registrar by Ford/DaimlerChrysler/GM.

c. Services: Scope of accreditation includes: agriculture; fishing; mining and quarrying; food products, beverages and tobacco; textile and textile products; pulp, paper and paper products; publishing and printing; manufacture of coke and refined petroleum products; nuclear fuel; chemicals, chemical products and fibers; pharmaceuticals; rubber and plastic products; non-metallic mineral products; concrete, cement, lime and plaster; basic metals and fabricated metal products; machinery and equipment; electrical and optical equipment; shipbuilding; wholesale and retail trade; repair of motor vehicles, motorcycles and personal and household goods; transport, storage and communication; financial intermediation; real estate; renting; information technology; engineering and other services; public administration; education; health; social work and services; public administration; education; health; social work and services. Maintains offices in Halifax, Montreal, Ottawa, Toronto, Calgary, Pittsburgh and Washington, D.C. 
ISO 9000, ISO 14000 and QS-9000 training and registration services are offered. Also offers assessments to AS9100. Offers assessments to ISO 13485 \& 13488 on medical devices (accreditation in progress with SCC).

48) International Standards Authority (ISA)

1305 West Arrow Highway, \#207

San Dimas, CA 91773

Phone: (909) 305-4900 (Contact: Jamie Topete)

Fax: none reported

E-Mail: jamiet@isaregistrar.com

URL: www.isaregistrar.com

Other Information:

a. Accredited by: ANSI-RAB for ISO 9001.

b. Other Program Recognition: none reported.

c. Services: contact registrar directly as above for specific details

d. Has applied for accreditation by ANSI-RAB's NAP for ISO 14000 EMS.

49) ITS Intertek Services (ITS)

4317-A Park Drive, N.W.

Norcross, GA 30093

Phone: (770) 925-2444 (Contact: Andrew Cole)

Fax: (770) 925-7294

E-Mail: acole@itsqs.com

URL: www.itsglobal.com

OR

ITS Intertek Testing Services, NA, Inc.

70 Codman Hill Rd.

Boxborough, MA 01719

Phone: (978) 929-2100 x115 (Contact: Daniel Desilets)

Fax: (978) 635-8595

E-Mail: ddesilet@itsintertek.com

URL: www.itsintertek.com

Other Information:

a. Accredited by: RvA (Netherlands), ANSI-RAB, UKAS (U.K.) and SCC (Canada).

b. Other Program Recognition: QS-9000 qualified registrar by Ford/DaimlerChrysler/GM.

c. Services: Scope of accreditation includes: aerospace; basic metals and fabricated metals; electrical and optical equipment; food and kindred products; machinery and equipment; paper and allied products; pharmaceuticals; railroad equipment; stone, clay, glass and concrete products; transportation and storage; engineering, 
accounting, research, management and related services; business services; chemicals; chemical products and fibers; finance and insurance; information technology; motor vehicles and equipment; petroleum refining and related industries; printing; publishing and allied industries; rubber and plastic products; textiles; wholesale trade and distribution. Member of LAAR. Lead assessors are registered with IRCA. Also has MDD (Medical Devices) CE markings for EU in medical products through the Swedish affiliate, ETL SEMKO, (European Testing Laboratory/SEMKO). Also accredited by UKAS (U.K.) for BS 7750/ISO 14001 and offers registration services for ISO 14000, AS9100, ISO 13485/88, ISO/TS 16949, ISO/IES 17025, EN 46000, SA 8000, VDA 6.1, TE Supplement \& TL 9000. An IATF recognized certification body. Intertek Testing Services is America's first ISO 9000 and ISO 14001 -accredited registrar. For more information on registration services, visit www.itsintertek.com online. Through its ETL SEMKO division, ITS also c ffers product safety testing and certification, EMC (Electromagnetic Compatibility) testing and performance evaluations globally. See below for ITS Quebec office.

50) Intertek Testing Services, NA, Ltd. - Canada

(ITS Intertek/Canada)

$1829,32^{\text {nd }}$ Avenue

Lachine, Quebec J7G 2L4

Phone: (514) 631-3100 or 877-779-4357

Fax: (514) 631-1133

E-Mail: none reported

URL: www.itsintertek.com

Other Information:

a. Accredited by: SCC (Canada).

b. Other Program Recognition: QS-9000 qualified registrar by Standards Council of Canada. Also provides CE Marking for EU. Offers assessments to EN 46000, ISO 13485, ISO 14000, TL 9000, ISO 17025 (in process) and SA 8000.

c. Services: Scope of accreditation: Includes the following SICs: 8, 13, 14,15, 16, $17,20,21,23,24,25,26,28,29,30,32,33,34,35,36,37,39,40,41,42,44,45$, $46,47,48,50,51,52,53,54,55,56,57,58,59,60,61,62,63,64,65,66,67,70$, $71,73,76,78,81,86,87$ and 95 . Scope includes part of the following SICs: 27 , $31,38,49,75,82$, and 83 . ITS Intertek is accredited for almost all NACE (List of Economic Activities for the European Union) in forestry, logging and related services; mining and quarrying; food products, beverages and tobacco; textiles products; leather and leather-products; wood and wood products; pulp, paper and paper products; printing companies; manufacture of refined petroleum products; chemicals, chemical products and fibers; pharmaceuticals; rubber and plastic products; non-metallic mineral products; concrete, cement, lime, plaster, etc.; basic metals and fabricated metal products; machinery and equipment; electrical equipment; shipbuilding; aerospace; other transport equipment; manufacturing not 
elsewhere classified; recycling; water supply; construction; financial intermediation; information technology; architectural and engineering services; other services; public administration; adult and other education services; and other social services. Has issued 1,300 ISO 9000 certificates and ISO 14000 (EMS) accreditation. Also has regional offices in Mississauga, $O N$, Calgary, $A B$ and Coquitlam, BC. International offices are maintained through the U.S., Mexico, Europe and Asia/Pacific. Registration validity period is 3 years, with surveillance audits conducted at 9 or 12 -month intervals. Surveillance audits with no reassessment at the end of the 3-year period are also available. Conduct of assessments to ISO 13485 in conjunction with Health Canada Requirements is in process. Also conducts assessments to AS9100.

51) ISOQAR, Inc. (ISOQAR)

166 Forbes Rd., Suite 203

Braintree, MA 02184

Phone: (781) 356-6572 (Contact: Andy Smith)

Fax: (781) 848-4749

E-Mail: isoqarusa@isogar.com

URL: www.isoqar.com

Other Information:

a. Accredited by: UKAS (U.K.) and ANSI-RAB for ISO 9001.

b. Other Program Recognition: QS-9000 qualified registrar by Ford/DaimlerChrysler/GM.

c. Services: Specializes in service to small to medium-sized organizations. Scope of accreditation includes: abrasive products; agriculture and horticulture; business services; chemicals and chemical products; electrical and electronic engineering; food, drink and tobacco industries; timber and wooden furniture; health services; general construction; Instrument engineering; metal goods; mineral oil refining; clothing industries; man-made fibers; mechanical engineering; metal goods; mineral oil refining; motor vehicle parts; office machinery and data processing equipment; paper products; rubber and plastic products; textile industry; telemarketing services; sanitary services; distributors; ships services; transportation. Member of IAAR. Has over 2,000 registered clients with offices worldwide. Offers assessments to ISO 14001.

52) KEMA Registered Quality (KRQ)

4377 County Line Road

Chalfont, PA 18914

Phone: (215) 997-4519 x304 (Contact: Ivy Peters)

Fax: (215) 997-3809

E-Mail: ipeters@krqusa.com

URL: www.krqusa.com; 
www.kema.nl

Other Information:

a. Accredited by: RvA (Netherlands). Accredited by ANSI-RAB for ISO 9001 and ISO 14001.

b. Other Program Recognition: ITQS recognition. Has MOUs with UL (USA), QMI (Canada) and JQA (Japanese Quality Association) (Japan). Parent body (NV KEMA) is accredited by RvA (Netherlands). KEMA is Notified Body offering $\mathrm{CE}$ marking services for regulated products marketed in the EU in areas of medical products, telecommunications, machinery and electromagnetic compatibility. QS-9000 qualified registrar by Ford/DaimlerChrysler/GM.

c. Services: Scope of accreditation includes: agriculture; chemicals; chemical products and fibers; rubber and plastic products; basic metals and fabricated metal products; machinery and equipment; aerospace; electrical and optical equipment; transport equipment; paper and allied products; stone/glass products; warehousing; jewelry and related articles; music instruments; sport goods; games and toys; electricity supply; gas supply; water supply; wholesale and retail trade; repair of motor vehicles; motorcycles; personal and household goods; information technology; and engineering services. Member of IQNET and IAAR. Three regional offices in U.S. Offers assessments to AS9100 and TL 9000. Offers assessments to ISO 13485, EN 4600 Medical QMS and is a Notified Body for CE Marking of related products for the EU.

53) Kemper Registrar Services, Inc. (See Bureau Veritas Quality International (N.A.) Inc./BVQI in above entry.)

54) KPMG Quality Registrar (KPMGQR) [Note: as of March 1, 2002, refer to BSI entry above]

150 John F. Kennedy Pkwy.

Short Hills, NJ 07078

Phone: 1-800-716-5595 (Contact: Kelli Gallagher/Axel Breidenbruch)

Fax: (973) 912-6050

E-Mail: kgallagher@kpmg.com

URL: www.us.kpmg.com/qualreg

OR

KPMG Quality Registrar Inc. (Canada)

Commerce Court West, Suite 3300

P.O. Box 31

Toronto, Ontario M5L 1B2 Canada

Phone: (416) 777-8755; 1-800-862-6752 (Contact: Mark J. O’Sullivan)

Fax: (416) 777-8818

E-Mail: none reported

URL: http://www.kpmg.ca 
Other Information:

a. Accredited by: ANSI-RAB for ISO 9001. JAS-ANZ (Australia and New Zealand). SCC (Canada).

b. Other Program Recognition: QS-9000 qualified registrar by Ford/Daimler Chrysler/GM. Has MOU with SIRA. Offers CE mark and TickIT certification through UKAS (U.K.).

c. Services: Member of IAAR. One of the big six accounting quality system registrars. Pursuing associations in India, Korea (Republic of), Mexico and other regions of the world. Offers assessments to ISO 14000 \& TL 9000. An IATF recognized certification body.

55) LLD, Inc.

500 Grove Street, $3^{\text {rd }}$ Flr.

Herndon, VA 20170

Phone: (703) 925-0660 (Contact: Mark Birch)

Fax: (703) 925-9441

E-Mail: ems@,corp.LLD.com

URL: www.lld.com

Other Information:

a. Accredited by: LLD, Inc us accredited by the ANSI-RAB NAP for ISO ISO 14001.

b. Other Program Recognition: none reported.

c. Services: For scope of accreditation contact the above website for LLD, Inc.

56) Lloyd's Register Quality Assurance, Ltd. (LRQA)

1401 Enclave Pkwy., Ste. 200

Houston, TX 77077

Phone: (281) 398-7370 (Contact: Jay Freeman)

Fax: (281) 398-7337

E-Mail: jay.freeman@lrqa.com

URL: www.lrqausa.com

Other Information:

a. Accredited by: RvA (Netherlands), UKAS (U.K.), ANSI-RAB for ISO 9001 and ISO 14001, INMETRO (Brazil), COFRAC (France), JAB (Japan), SCC (Canada), JAS-ANZ (Australia-New Zealand), SWEDAC (Sweden), SINCERT (Italy), TGA (Germany), KAB (Republic of Korea) BELCERT (Belgium), SPSB (Singapore Productivity and Standards Board) (Singapore), ENAC (Spain), HKCAS (Hong Kong Certification Body Accreditation Scheme) (Hong Kong, People's Republic of China), IPQ (Portugal) and ENAC (Spain). 
b. Other Program Recognition: Accredited by the UKAS (U.K.) under the TickIT certification scheme for software development. QS-9000 qualified registrar by Ford/DaimlerChrysler/GM.

c. Services: Uses lead assessors that are IRCA registered. Member of IAAR. LRQA has issued ISO 14000 and ISO 9000 registration certificates to more than 20,000 organizations in over 100 countries. LRQA offers registration to ISO 9000 , AS9100, TL 9000, QS-9000 and ISO 14000. LRQA is also a Notified Body for CE Marking under the EU Directives. LRQA offers a full range of commercial training courses including accredited Lead Auditor for ISO 9000 and ISO 14000. Offers assessments to VDA 6.1, HACCP (Hazard Analysis Critical Control Point), TE Supplement and ISO/TS 16949, EU Directives for Medical Devices and In-Vitro Diagnostics, Environmental Product Declaration and Report Verification and OHSAS 18000 (Health Safety).

57) National Quality Assurance, U.S.A. (NQA, USA)

4 Post Office Square Road

Acton, MA 01720

Phone: (978) 635-9256 (Contact: Derek Coppinger)

Fax: (978) 263-0785

E-Mail: dcoppinger@nqa-usa.com

URL: http://www.nqa-usa.com

a. Accredited by: NQA, USA is one of the most experienced and widely accredited registrars in the world. International acceptance of certificate is provided through ANSI-RAB for ISO 9001 and ISO 14001, RvA (The Netherlands) and NACB (National Accreditation of Certification Bodies) (U.K.).

b. Other Program Recognition: QS-9000 qualified registrar by Ford/DaimlerChrysler/GM. Also accredited by the UKAS (U.K.) under the TickIT certification scheme. TL 9000 approved. ISO 17025 approval pending.

c. Services: Has performed over 13,000 ISO 9000, ISO 14000 and QS-9000 assessments worldwide. Member of IAAR. Provides a common sense and cost effective approach to the registration process combined with superior reputation for value added service. Specializes in aerospace and electronics. Offers an entire range of services includes assessments to ISO 9001, ISO 9002, QS-9000 and AS9100. Also, offers assessment to ISO/IEC Guide 25 and AC-0056. Provides training, internal audits and supplier audits. Offers assessments to ISO 9001:2000, AS9100 and TL 9000.

58) NSF International Strategic Registrations, Ltd. (NSF-ISR)

(A subsidiary of NSF International)

789 N Dixboro Rd.

Ann Arbor, MI 48105

Phone: (734) 827-6876 (Contact: Suzie Fourne) 
Fax: (734) 827-6801

E-Mail: fourne@nsf.org

URL: http://www.nsf-isr.org

Other Information:

a. Accredited by: RvA (Netherlands) and by ANSI-RAB for ISO 9001 and ISO 14001.

b. Other Program Recognition: Accredited by: Has MOUs with Moody's AOQC, IAS (formerly AGAL), QMI of CSA and also DSCC. Can offer joint assessment and registrations with registrars in the U.K. and other European countries, Israel, Australia, Canada, Japan and other selected Asian countries. In addition to ISO 9000, is a QS-9000 qualified registrar by Ford/DaimlerChrysler/GM.

c. Services: Lead assessors are registered with IRCA/RAB. Member of IAAR. Offers assessments to TE Supplement, HACCP and HACCP 9000, Trademark Quality Registration for the Food Industry. Also, offers assessments to ISO 9001:2000. Offers analysis and preliminary assessments through parent company as well as a series of training courses in ISO 9000 and 14001. Also offers assessments to AS9100.

59) National Standards Authority of Ireland (NSAI)

402 Amherst Street

Nashua, NH 03063

OR

39159 Paseo Padre Parkway, Suite 232

Fremont, CA 94538

Phone: (603) 882-4412 (Contact: Thomas L. Byrne)

(510) 713-0292 (Contact: Donna Wood/Randy Rabitz)

Fax: (603) 882-1985 (eastern region)

(510) 713-0294 (western region)

E-Mail: certification@nsai.ie

URL: www.nsai.ie

Other Information:

a. Accredited by: NSAI was accredited by ANSI-RAB NAP for ISO 9001. Through an Act of Irish Parliament it was notified to the EU. Operates under the Irish Science and Technology Agency. Accredited by the Irish government for registration of ISO 9000/EN 29000.

b. Other Program Recognition: Has reciprocal recognition for its registrations in all EU and EFTA countries without further assessment upon payment of the necessary registration fees. Also has a bilateral agreement with CGSB (Canadian General Standards Board) (Canada). Is pursuing additional bilateral agreements. Is a QS-9000 qualified registrar by Ford/DaimlerChrysler/GM.

c. Services: All NSAI's lead assessors are registered with IRCA. NSAI has been registering companies to the Irish Environmental Standard for the past four years. Member of IQNET, the International Certification Network. Also, offers 
assessments to ISO 14001 and EN 46000 on medical devices. EU notified body for a wide range of EU directives. NSAI is a fully integrated standards publishing and certification body. Overseas office: NSAI, Maria McKeown, Glasnevin, Dublin 9, Ireland; phone: 0113531807 3800; fax: 0113531807 3844; e-mail: mckeownm@nsai.ie; web: www.nsai.ie. Member of IAAR.

60) Orion Registrar Inc.

7850 Vance Drive, \#210

Arvada, CO 80003

Phone: (303) 456-6010 (Contact: Kaci Fults)

Fax: (303) 456-6681

E-Mail: info@orion-iso.com

URL: www.orion-iso.com

Other Information:

a. Accredited by: RvA (Netherlands). SCC (Canada). ANSI-RAB for ISO 9001 and ISO 14001.

b. Other Program Recognition: QS-9000 qualified registrar by Ford/DaimlerChrysler/GM.

c. Services: Scope of accreditation includes: pulp, paper and paper products (7); printing companies (9); chemicals, chemical products and fibers, limited to blending and purification activities through filtering (12); pharmaceuticals, limited to drugs and therapeutic products (13); rubber and plastic products (14); basic metals and fabricated metal products (17); machinery and equipment (18); electrical and optical equipment (19); wholesale and retail trade, repair of motor vehicles, motorcycles and personal and household goods (29); information technology (33); and other professional services (35). Additional EAC/SIC codes are: $13 / 28-14 / 30-16 / 32-17 / 33,34-18 / 35-22 / 38$, 37. Also, has MOU with NEMKO (Norwegian Certification Entity for Information Technology and Telecommunications) (Norway) for CE Mark; blood banks. Conducts assessments to ISO 14001, AS9100, TL 9000, ISO 13485, EN 46001 and MDD CE Marking requirements.

61) OTS Quality Registrars (OTSQR)

3726 Dacoma St.

Houston, TX 77092

Phone: (713) 683-2290 (Contact: Ron Platt)

Fax: (713) 683-2283

E-Mail: info@otsqr.com

URL: http://www.otsqr.com

Other Information: 
a. Accredited by: RvA (Netherlands).

b. Other Program Recognition: none reported.

c. Services: Scope of accreditation under the OTSQR Quality System Registration includes: mining, quarrying, chemicals, fibers, rubber, plastics, metals, machinery and equipment, wholesale trade (distributors), business services, transportation and electrical/optical equipment, including semiconductors, aerospace, automotive and small to mid-size companies and large or multi-site corporations. IRCA/RAB registered auditors. Also conducts registration audits to requirements of ISO 9001: 1994E and ISO 9002: 1994E.

62) Performance Review Institute Registrar (PRI)

161 Thornhill Road

Warrendale, PA 15086-7527

Phone: (724) $772-7170$ (Contact: J. L. Borczyk)

Fax: (724) 772-1699

E-Mail: jborczyk@sae.org

URL: www.pri.sae.org

Other Information:

a. Accredited by: ANSI-RAB for ISO 9001 and ISO 14001 and by RvA (Netherlands).

b. Other Program Recognition: QS-9000 qualified registrar by Ford/DaimlerChrysler/GM.

c. Services: Scope of accreditation includes: ground vehicle and aerospace industry. Conducts assessment to AS9100, Customized Industrial Programs and ISO 14001. PRI is affiliated with SAE (Society of Automotive Engineers). Member of IAAR. Conducts assessments to QS-9000 TE Supplement. Also, AS9100.

63) Perry Johnson Registrars, Inc. (PJR)

26555 Evergreen Road, Ste. 1340

Southfield, MI 48076

Phone: 1-800-800-7910 (Contact: Terry Boboige)

Fax: (248) 358-0882

E-Mail: pir@pir.com

URL: www.pjr.com

Other Information:

a. Accredited by: ANSI-RAB for ISO 9001 and ISO 14001, and by RvA (Netherlands), JAB (Japanese Accreditation Board for Conformity Assessment) and KBA (German Federal Motor and Transport Authority). Applications are pending with UKAS (U.K.), TGA (German Association for Accreditation) and INMETRO (Brazil). 
b. Other Program Recognition: QS-9000 qualified registrar by Ford/DaimlerChrysler/GM.

c. Services: Scope of accreditation includes: EAC codes 2, 3, 4, 5, 6, 7, 8, 9, 12, 14, $17,18,19,21,22,23,28,29,30,31,35,37$ and 40 . PJR provides $3^{\text {rd }}$ party audits for ISO 9000, ISO 14000, QS-9000, AS9100, VDA 6.1, ISO/IEC Guide 25 and TE Supplement. Domestic offices: Detroit (Southfield \& Grand Rapids), Boston, Chicago, Los Angeles, Dallas, Philadelphia, Cleveland, Colorado, Florida, Indiana, Minnesota, Missouri and North Carolina. Global offices: Monterrey \& Mexico City, Mexico; Hiroshima, Osaka and Tokyo, Japan; Brazil and Germany. Member of IAAR. Also conducts TL 9000 assessments.

64) Professional Registrar Organization, Inc. (PRO, INC)

3150 Livernois, Suite 270

Troy, MI 48083

Phone: (248) 593-6511; 1-800-793-4408 (Contact: Chuck Schleyer)

Fax: (248) 593-6518

E-Mail: Charles Schleyer@earthtech.com

URL: www.proregistrar.com

Other Information:

a. Accredited by: ANSI-RAB for ISO 9001 and ISO 14001.

b. Other Program Recognition: QS-9000 qualified registrar by Ford/DaimlerChrysler/GM.

c. Services: Scope of accreditation includes: agricultural production crops; paper and allied products; chemicals and allied products; petroleum and coal products; primary metal industries; computers; transportation equipment; aircraft; aerospace; instruments and related products; medical instruments; miscellaneous manufacturing; U.S. Postal Service; transportation by air; wholesale tradedurable goods; wholesale trade - nondurable goods; business services; health services; legal services; engineering and management services; services; environmental quality and housing. Also, oil and gas extraction (SIC \#13); printing ink (SIC \#2893); rubber and miscellaneous plastics products (SIC \#30); flat glass (SIC \#321); products of purchased glass (SIC \#323); fabricated metal products (SIC \#34); industrial machinery (SIC \#35); electronic and other electric equipment (SIC \# 36); motor vehicles and equipment (SIC \#371); motorcycles, bicycles and parts (SIC \#375); miscellaneous transportation equipment (SIC \#379); miscellaneous manufacturing industries (SIC \#39); and personal services (SIC \#72). PRO was formed by a group of ISO professionals with extensive experience in auditing, instruction and various technical services.

65) Quality Certification Bureau, Inc. (QCB)

Advanced Technology Center

9650 - 20th Avenue, Suite 103 
Edmonton, Alberta T6N 1G1 Canada

Phone: (780) 496-2463 (Contact: Han Visser)

Fax: (780) 496-2464

E-Mail: hanv@gcbinc.com

URL: www.qcbinc.com

Other Information:

a. Accredited by: SCC (Canada) and RvA (Netherlands).

b. Other Program Recognition: QS-9000 qualified registrar by Ford/DaimlerChrysler/GM.

c. Services: Scope of accreditation includes: EAC 2 - mining and quarrying; 3 food, beverages and tobacco; 4 - textiles and textile products $\left({ }^{*}\right) ; 6$ - wood and wood products; 7 - pulp, paper and paper products; 9 - printing companies; $10-$ manufacture of coke and refined petroleum products $(*) ; 12$ - chemicals, chemical products and fibers; 14 -rubber and plastic products; 15 - nonmetallic mineral products $\left({ }^{*}\right) ; 16$ - concrete, cement, lime, plaster, etc.; 17 - basic metals and fabricated metals; 18 - machinery and equipment; 19 - electrical and optical equipment; 21 - aerospace; 22 - other transport equipment; 28 - construction $\left({ }^{*}\right)$; 29 - wholesale and retail trade, repair of motor vehicles, motorcycles and personal and household goods; 31 - transport, storage and communication(*); 34 - engineering services; 35 - other professional services(*); 37 - education; 38 health and social services. (Note: ${ }^{*}=$ limited scope) Conducts assessment to ISO 9000 and ISO 14000. Member of LAAR.

66) Quality Management Institute (QMI) [Div. of the Canadian Stds. Assoc. (CSA)]

90 Burnhamthorpe Rd., W., Ste. 300

Mississauga, Ontario L5B 3C3 Canada

Phone: 1-800-465-3717 (Contact: Barbara Frost)

Fax: (905) 272-4538

E-Mail: clientservices@qumi.com

URL: http://www.qmi.com

OR

QMI

8501 E. Pleasant Valley Rd.

Cleveland, $\mathrm{OH}$ 44131-5575

Phone: (216) 901-1911 (Contact: Jim Solich)

Fax: (216) 520-8967

E-Mail: jsolich@qmi.com

URL: www.qmi.com

OR

QMI

900 W. Sproul Rd., Ste. 103

Springfield, PA 19064

Phone: (610) 544-7880 (Contact: Bud Cuthbert/Sharon Berckman)

Fax: (610) 544-9682 
E-Mail: bcuthbert@gmi.com

URL: http://www.qmi.com

Other Information:

a. Accredited by: SCC (Canada), RvA (Netherlands), EMA and ANSI-RAB for ISO 9001 and ISO 14001.

b. Other Program Recognition: Has full MOUs (bilateral agreements) with AENOR (Spain), AFAQ (France), BSI QA (U.K.), DQS (Germany), DS (Denmark), IMQ (Italy), JQA (Japan), KEMA (Netherlands), OQS (Austria), QAS (Australia), SISIR (Singapore), SNZ (New Zealand), SIS (Sweden), SQS (Switzerland), TELARC (New Zealand) and UL (USA). MOUs in development with BCIQ (Taiwan), CISQ (Italy), IMNC (Mexico), KAITECH (Republic of Korea), KSA QA (Republic of Korea), NCS (Norway), SFS (Finlạnd), SII (Israel) and SIRIM (Malaysia). QS-9000 qualified registrar by Ford/Daimle:Chrysler/GM. Offers registration services in Sustainable Forest Management System CAN/CSA (Canadian Standards Association) Z809.

c. Services: QMI's applicants comprise major industry segments under SCC (Canada), RvA (Netherlands) and ANSI-RAB, including: forestry; telecommunications; petrochemical; chemical; electrical and electronics; pulp and paper; mechanical; mining; transportation; service sectors; and engineering and management services. SCC accreditation allows registration in all industry segments. Maintains other hub offices in Calgary/Alberta, Montreal/Quebec and Vancouver/British Columbia, Canada; Cleveland, OH; Irvine, CA; Philadelphia, PA; and Mexico City, Mexico. Also maintains satellites in Kowloon, People's Republic of China; Charlotte, NC; Chicago, IL; Detroit, MI; Nashua, NH and San Francisco, CA. Operates QMI Agents in Halifax and Kingston, Canada; Islamic Republic of Iran; Lebanon; and Turkey. Member of IAAR. Accredited for Environmental Management System (EMS) ISO 14000 by SCC. QMI is a full member of IQNET. QMI is an IATF recognized certification body. Offers assessments to TL 9000 (SCC and RAB); AS9100; ISO/TS 16949; TE Supplement to QS-9000; ISO/IEC 17025 (not accredited, but can conduct audits on behalf on L-A-B which issues reports/certificates); CAN/CSA Q830-96 Privacy Code; CAN/CSA B619-00 Carrier Safety Management Systems (not accredited); ISO 13485 \& ISO 13488; ISO/TS 16949; and TAPA (Technology Asset Protection Association) Minimum Security Requirements.

67) Quality Services International (QSI)

12350 SW 132 Court, Ste. 206

Miami, FL 33186

Phone: (786) 293-2053 (Contact: Celso Alvarado)

Fax: (786) 293-9137

E-Mail: qsicelso@aol.com

URL: www.qsiamerica.com

Other Information: 
a. Accredited by: ANSI-RAB for ISO 9001 and by IAR for ISO 14001 .

b. Other Program Recognition: Accreditation currently in process with ANSI-RAB for QS-9000.

c. Services: Provides auditing services for SA 8000, TL 9000, HACCP, ISO 9000 and ISO14000 through IAR. Also conducts assessments to ISO 17025 and ISO/TS 16949.

68) Quality Systems Registrars, Inc. (QSR)

13873 Park Center Road, Suite 217

Herndon, VA 20171

Phone: (703) 318-3151 (Contact: Scott Kleckner)

Fax: (703) 478-0541

E-Mail: scottk@gsr.com

URL: www.qsr.com

Other Information:

a. Accredited by: ANSI-RAB for ISO 9001 and ISO 14000 and by RvA (Netherlands).

b. Other Program Recognition: QS-9000 qualified registrar by Ford/DaimlerChrysler/GM.

c. Services: Scope of accreditation includes: mining; oil and gas extraction; food products; textiles; lumber; paper, pulp and allied products; printing; chemicals and allied products; petroleum refining; rubber and plastics; primary metal production; fabricated metal products; electronic equipment; transportation equipment; measuring instruments; pipelines; wholesale trade; and engineering/accounting/research services. Evaluators meet IRCA/RAB requirements for lead auditors. Member of IAAR. Conducts assessments to AS 9100 and TL 9000.

69) QUASAR

Quality Systems Assessment Registrar

(A Division of the Canadian Welding Bureau)

7250 West Credit Avenue

Mississauga, Ontario L5N 5N1 Canada

Phone: (905) 542-0547, 1-800-461-9001 (Contact: Doug Luciani)

Fax: (905) 542-1318

E-Mail: doug.luciani@cwbgroup.com

URL: www.cwbgroup.com

Other Information:

a. Accredited by: SCC (Canada).

b. Other Program Recognition: Pursuing QS-9000 qualified registrar status by Ford/DaimlerChrysler/GM. 
c. Services: Scope of accreditation includes: mining; quarrying; chemicals, chemical products and manmade fibers; nonmetallic mineral products; basic metal and fabricated metal products; electrical and optical equipment; aerospace; electric supply; wholesale and retail trade; transportation, storage and communication; printing; rubber and plastic products; concrete, cement, lime and plaster; machinery; shipbuilding; other transport equipment; construction; information technology; and engineering services. Specializes in ISO 9000 awareness, documentation and implementation, internal auditor training and lead auditor training. Also conducts assessments to TL 9000 and ISO 14000.

70) SGS International Certification Services Canada Inc. (SGS ICS) - Canada Unit 2, 6275 Northam Drive

Mississauga, Ontario L4V 1 Y8 Canada

Phone: (905) 676-9595

Fax: (905) 676-9362

E-Mail: info@sgsna.com

URL: www.sgs.ca

Other Information:

a. Accredited by: SCC (Canada) for ISO 9001 and ISO 14001, UKAS (U.K.), ANSI-RAB NOT ON THEIR LIST!!!, SINCERT (Italy), INMETRO (Brazil), DAR/TGA (Germany), BELCERT (Belgium), INN (Chile), SAS (Switzerland), JAS-ANZ (Australia-New Zealand), JAB (Japan), COFRAC (France), ENAC (Spain) and SECOFI (Mexico).

b. Other Program Recognition: QS-9000 qualified registrar by Ford/DaimlerChrysler/GM.

c. Services: SGS ICS is one of the largest independent quality systems registrars in the world, operating internationally in more than 60 countries. With offices in North America, South America, Europe, Africa, Australia and Asia, SGS ICS has registered over 13,000 companies worldwide. SGS ICS Canada, Inc. offers worldwide registration and training services to ISO 9000, QS-9000, CE markings and TickIT Software Standard. Scope of accreditation includes: agriculture and fishing; leather and leather products; wood and wood products; pulp/paper and paper products; publishing companies; printing companies; manufacture of coke and refined petroleum products; chemicals (chemical products and fibers); pharmaceuticals; rubber and plastics products; non-metallic mineral products; concrete/cement/lime/plaster; basic metals and fabricated metal products; machinery and equipment; electrical and optical equipment; aerospace; transport equipment; construction; wholesale and retail trade; hotels and restaurants; transport (storage and communication); financial intermediation; information technology; engineering services; public administration; education; health and social services. Also offers assessments to SA 8000, Green Globe Certification and HACCP Certification. Provides training services. 
71) SGS International Certification Services, Inc. (SGS ICS, Inc.) - United States 201 Route 17 North

Rutherford, NJ 07070

Phone: (201) 935-1500 x224 (Contact: Malcolm Ting)

Fax: (201) 935-4555

E-Mail: malcolm ting@sgsicsus.com

URL: www.sgsicsus.com

Other Information:

a. Accredited by: ANSI-RAB for ISO 9001 and ISO 14001. SGS ICS worldwide network can also offer UKAS (U.K.), BELCERT (Belgium), JAS-ANZ (Australia/New Zealand), SINCERT (Italy), SAS (Switzerland), DAR/TGA (Germany), INMETRO (Brazil), SCC (Canada), JAB (Japan) and INN (Instituto Nacional de Normalizacion) (Chile). Accreditation for Social Accountability (SA 8000) Audits granted to SGS by the Council on Economic Priorities (CEP).

b. Other Program Recognition: QS-9000 qualified registrar by Ford/DaimlerChrysler/GM. Also a Notified Body to EU.

c. Services: Additional certification offices in Mexico, Brazil, Canada, Europe and Pacific Basin. Additional offices in Houston, TX; Lombard, IL; Los Angeles, CA; Hampstead, NH; Charlotte, NC; and Fremont, CA. Member of IAAR. Also qualified to perform AS9100 audits. Offers ISO 9000, QS-9000/TE Supplement, ISO 14001, CE Marking, ISO 9000 for Healthcare, SA 8000, TL 9000 Green Globe assessments.

72) Smithers Quality Assessments, Inc. (SQA)

425 West Market Street

Akron, $\mathrm{OH} 44303$

Phone: (330) 762-4231 (Contact: Russ Bloom)

Fax: (330) 762-7447

E-Mail: rbloom@smithersmail.com

URL: www.smithersregistrar.com

Other Information:

a. Accredited by: RvA (Netherlands). ANSI-RAB for ISO9001 and ISO 14001.

b. Other Program Recognition: QS-9000 qualified registrar by Ford/DaimlerChrysler/GM. An IATF-recognized certification body.

c. Services: Scope of accreditation includes: aircraft, automotive; basic materials; bearings and gears; elastomerics; electrical and optical; equipment manufacturing; fabricated metal products; general electric aircraft engines; guided missiles and space vehicles; motor vehicle wheels; parts and accessories; printing; rubber and plastic products; and wholesale, non-durable goods. Member of IAAR. Offers ISO 9001, 9002 and 9003 services. Also ISO 14001 EMS and AS9100 
assessments. Offers assessments to ISO/ TS 16949, TE Supplement, ISO 9001: 2000, TL 9000 and ISO/IES 17025 with Laboratory Accreditation Bureau.

73) SRI Quality System Registrar, Inc. (SRI)

2000 Corporate Drive, Suite 580

Wexford, PA 15090

Phone: (724) 934-9000 (Contact: Peter Lake)

Fax: (724) 935-6825

E-Mail: lake@sriregistrar.com

URL: http://www.sriregistrar.com

Other Information:

a. Accredited by: ANSI-RAB for ISO 9001 and ISO 14001, and by RvA (Netherlands) and IAOB.

b. Other Program Recognition: QS-9000 qualified registrar by Ford/DaimlerChrysler/GM. An IATF-recognized certification body.

c. Services: Scope of accreditation includes: mining; quarrying; food products; beverages; tobacco; wood and wood products; pulp, paper and paper products; coke and refined petroleum products; chemicals, chemical products and fibers; rubber and plastic products; nonmetallic mineral products; concrete, cement, lime, plaster, etc; basic metals and fabricated metal products; machinery and equipment; electrical and optical equipment; aerospace; other transport equipment; manufacturing not elsewhere classified; recycling; construction; wholesale and retail trade; repair of motor vehicles; motorcycles; personal and household goods; transport, storage and communications; engineering services; other services; education. The IAF scope categories are 02, 03, 06, 07, 10, 12, 14, $15,16,17,18,19,21,22,23,24,28,29,31,34,35$ and 37. Member of IAAR. Also is a registrar for ISO 14001. Offers assessments to AS9100. Also offers laboratory evaluation, education, rolling stock for railway industry - locomotives and aerospace services. Conducts assessment to AAR (Association of American Railroads) M-1003 (specification on manufacture of cast steel wheels and axles). TE/QS-9000 underway. Also conducts assessments to ISO Guide 25. Conducts assessments to ISO/TS 16949; ISO 9001, 9002, 9003 (1994); ISO 17025, as affiliate to Laboratory Accreditation Bureau; AAR M-1003 assessments; TE Supplement; TL 9000; ISO 14000; and ISO/TS 16949.

74) STR-Registrar, LLC

24 Scitico Road

Somersville, CT 06072

Phone: (860) 763-7013 (Contact: Jim Galica)

Fax: (860) 763-7017

E-Mail: james.galica@str-r.com

URL: www.str-r.com 
Other Information:

a. Accredited by: ANSI-RAB for ISO 9001.

b. Other Program Recognition: none reported.

c. Services: Scope of accreditation: IAF scope categories for 04 Textiles and Textile Products; 07 Pulp, Paper and Paper Products; 09 Printing Companies; 14 Rubber and Plastic Products; 17 Basic Metals and Fabricated Metal Products; 18 Machinery and Equipment; 23 Manufacturing Not Elsewhere Classified; 29 Wholesale and Retail Trade; Repair of Motor Vehicles, Motorcycles and Personal and Household Goods; 30 Hotels and Restaurants; 31 Transport, Storage and Communications; 36 Public Administration; 37 Education; 38 Health and Social Work; and 39 Other Social Services.

75) Telcordia Quality Registration (TQR)

[formerly Bellcore]

6 Corporate Place

Piscataway, NJ 08854

Phone: (732) 699-4246 (Contact: Peter Ortolani)

Fax: (732) 336-2244

E-Mail: portolan@telcordia.com

URL: tqr.telcordia.com

Other Information:

a. Accredited by: ANSI-RAB for ISO 9001.

b. Other Program Recognition: none reported.

c. Services: Scope of accreditation includes: electrical products; optics; transportation; storage; and communication/information technology; telecommunications - all phases. Conducts assessments to TL 9000. Member of IAAR.

76) The Registrar Company, Inc. (TRC)

P.O. Box 516186

Dallas, TX 75251-6186

Phone: (972) 931-3492 (Contact: Jennifer Sherman)

Fax: (972) 931-0367

E-Mail: ienni@theregistrarco.com

URL: theregistrarco.com

Other Information:

a. Accredited by: ANSI-RAB for ISO 9001.

b. Other Program Recognition: QS-9000 qualified registrar by Ford/DaimlerChrysler/GM. 
c. Services: Scope of accreditation includes: paper and allied products; rubber and miscellaneous plastics products; leather and leather products; primary metal industries; fabricated metal industries; industrial machinery and equipment; motor vehicle parts and accessories; instruments and related products; miscellaneous manufacturing industries; and testing laboratories. In addition, TRC has requested approval for extension of scope. Please contact TRC for current scope of accreditation. TRC is also in the process of applying for approved supplier status for ARD 9000. Utilizes only RAB/IRCA certified auditors. A national staff of professional, qualified auditors allows TRC to reduce additional registration costs. Will be offering TL 9000 and AS9100-accredited registration.

77) TRA Certification (TRA-CD)

700 E. Beardsley Avenue

Elkhart, IN 46514

Phone: (574) 264-0745 (Contact: Rob Podawiltz)

Fax: (574) 264-0740

E-Mail: rpodawiltz@trarnold.com

URL: www.tra-cd.com

Other Information:

a. Accredited by: ANSI-RAB for ISO 9001 and by RvA (Netherlands).

b. Other Program Recognition: QS-9000 qualified registrar by Ford/DaimlerChrysler/GM.

c. Services: Scope of accreditation includes: primary metals (castings, forging); fabricated metal (stampings, tools, pipe, wire); plastics and rubber; electrical and electronics; chemicals; wood products; industrial and commercial machinery; computer equipment; automotive; test laboratories; aerospace; industrial process control equipment; and measuring instruments. As a registrar of ISO/QS-9000 quality systems, TRA Certification offers a full range of third party assessment services leading to registration, including pre-assessment (on-site), document review, initial audit (on-site), registration and surveillance audits (on-site). Member of IAAR and AIAG. Also offers assessments to TL 9000 \& AS9100.

78) TUV Management Service (TMS)

5 Cherry Hill Drive

Danvers, MA 01923

Phone: (978) 739-7075 (Contact: David Dougherty)

Fax: (978) 762-8414

E-Mail:ddougherty@tuvam.com

URL: www.tuvglobal.com

Other Information: 
a. Accredited by: ANSI-RAB for ISO 9001 and ISO 14001 and by the German Accreditation Council (DAR/TGA) to provide ISO 9000, QS-9000 and ISO 14001 registration. Additional accreditations and authorizations include ANSIRAB for TE Supplement registration and the German Department of Transportation (KBA) and the Association of German Automotive Industry (VDA) for VDA 6.1 registration.

b. Other Program Recognition: TUV Product Service is accredited by the German Accreditation Body as a Notified Body (ZLG) for EN 46001, EN 46002, ISO 13485 and ISO 13488. Member of the TUV CERT organization. QS-9000 qualified registrar by Ford/DaimlerChrysler/GM and RAB/DAR recognized. General Electric Aircraft Engines (GEAE) approved AS9100 registrar. An IATFrecognized certification body.

c. Services: Scope of accreditation includes: plant and mechanical engineering; construction industry; chemistry/raw materials/energy; services; iron, steel and nonferrous metals; electrical and electronic products; automobile manufacture/supply companies; precision mechanics/optical products; glass ceramics; wood products and furniture; plastic products/rubber; medical devices; food and drink industry; printing; paper and packaging materials; textiles; transportation and logistics and much more. TUV has issued over 8,500 certificates in nearly 40 countries and maintains offices in San Diego, CA; Boulder, $\mathrm{CO}$; New Brighton, $\mathrm{MN}$; and 10 additional offices across North America. Member of LAAR. An international certification company, TUV Management Service/TUV Product Service represents one of the world's largest system and product certification organizations. As a European Union (EU) Notified and Competent Body, the array of services includes ISO 9000, QS-9000 and ISO 14001 registration. TUV also performs a variety of product and systemsrelated testing, inspection and certification services, creating single source solutions for management systems and product-related testing and certification. Services include CE marking assistance, electrical and mechanical safety, electromagnetic compatibility (EMC), telecommunications, medical devices and orthopedics testing and certification. In addition, working with BABT Product Service, TUV can provide BABT 340/940 audits and telecom related services. ISO/TS 16949. ISO 13485/13488. Also offers assessments to TE Supplement, TL 9000 and AS9100.

79) TUV CETECOM

411 Dixon Landing Rd.

Milpitas, CA 95035

Phone: 1-800-888-4630 (Contact: Hermann Ries)

Fax: (408) 586-6299

E-Mail: info@tuvessen.com

URL: www.tuvessen.com

OR

TUV Essen, Inc., Quality Systems Division 
4 Brighton Rd., Ste. 340

Clifton, NJ 07102

Phone: (973) 773-8880 (Contact: Melissa Manco)

Fax: (973) 773-8834

E-Mail: info@tuv.essen.com

URL: www.tuvessen.com

Other Information:

a. Accredited by: Parent company accredited by DAR (Germany). TGA (Germany). Accredited by ANSI-RAB for ISO 9001.

b. Other Program Recognition: Member of TUV CERT organization, which is a Notified Body to the EU. QS-9000 qualified registrar by Ford/DaimlerChrysler/GM. An IATF-recognized certification body.

c. Services: Scope of accreditation includes: automotive; chemicals and allied products computer and office equipment; pharmaceuticals and drugs; electronic and other electrical equipment and components; fabricated metal products; general manufacturing; industrial machinery and equipment; industrial paints, coatings and finishes; information technology; laboratory analytical equipment; measuring and controlling devices; medical devices; motor vehicles; office furniture; plastics, resins and elastomers; research, development and testing services; telecommunications; testing laboratories; leather and leather products; pulp, paper and paper products; engineering services. Has offices in MI and NJ. Provides ISO 14001 registration and CE marking services through parent company, RWTUV. Recently expanded scope to include the construction industry, finance, food and aerospace (AS9100). Conducts ISO/TS16949 and EN $46000 \mathrm{MDD}$ assessments via its parent company, RWTUV. Listed as \#1 in administrative efficiency and \#2 in overall customer satisfaction by Quality Digest survey in August 1999. Member of IAAR. Scope extended to IAF 21 Aerospace. Gateway to Radio and Telecommunication Terminal Equipment (R\&TTE) Certification and Bluetooth Qualification Body via CETECOM, Inc.

80) TUV Rheinland of North America, Inc. (TUVRNA)

182 Turnpike Rd., Ste. 91

Westborough, MA 01581

Phone: (508) 836-3366 x238 (Contact: Walter Sam O'Connor)

Fax: (508) 836-3601

E-Mail: soconnor@us.tuv.com

URL: http://www.tuv.com

Other Information:

a. Accredited by: RvA (Netherlands). Parent company accredited by DAR (Germany). Accredited by ANSI-RAB for ISO 9001 and ISO 14001. TL 9000accredited by ANSI-RAB. 
b. Other Program Recognition: QS-9000 qualified registrar by Ford/DaimlerChrysler/GM. Member of TUV CERT. A Notified Body for the EU. An IATF-recognized certification body.

c. Services: Has offices in 30 countries and around U.S. Member of IAAR. At present, conducts ISO 14001 registrations through TUV CERT. TUV Rheinland currently holds $39 \mathrm{EAC}$ codes in accreditations from the DAR/TGA and RvA for ISO 9000 and QS-9000. TUV is also able to provide VDA 6.1 registration for its automotive clients. Also conducts assessments to TL 9000 \& TE Supplement.

81) Underwriters Laboratories, Inc. (UL)

333 Pfingsten Road

Northbrook, IL 60062

Phone: 1-800-2UL-4ISO (285-4476) (Contact: Chris Trigsted/James Moy)

Fax: (847) 509-6219

E-Mail: registrar@ul.com

URL: http://www.ul.com

OR

Underwriters Laboratories, Inc. (UL)

Corporate Quality and Reliability Department or

Registration and Technical Services Department

1285 Walt Whitman Road

Melville, NY 11747

Phone: (631) 271-6200 ext. 22340 (Contact: Michael Caruso)

Fax: (631) 439-6022

E-Mail: Michael.J.Caruso@us.ul.com

URL: www.ul.com

Other Information:

a. Accredited by: RvA (Netherlands), SCC (Canada), UKAS (U.K.), and INMETRO (Brazil). Accredited by ANSI-RAB for SIO 9001 and ISO 14001

b. Other Program Recognition: To complement accreditations, UL has established a worldwide network through MOUs with 18 other registrars. Through these agreements, UL clients can gain access to registration from any of the MOU partners with one assessment. QS-9000 qualified registrar by

Ford/DaimlerChrysler/GM. An IATF-recognized certification body. UL is the U.S. National Supervising Inspectorate (NSI) for the IECQ system.

c. Services: Scope of accreditation includes: converted paper and paperboard products (except containers and boxes); industrial/inorganic chemicals; plastic materials and synthetic resins; synthetic rubber; cellulosic and other manmade fibers (except glass); plastic products; rolling, drawing and extruding of nonferrous metals; general industrial machinery and equipment; computer and office equipment; electric transmission and distribution equipment; electrical industrial apparatus; electric lightning and wiring equipment; communications equipment; electronic components and accessories; laboratory apparatus and 
analytical, optical, measuring and controlling instruments and supplies; electrical goods - wholesale trade; computer programming; data processing; food and kindred products; textile mill products; rubber and miscellaneous products; fabricated metal products; instruments and related products; business services and related products. Member of IAAR. Additionally, accredited by RAB for SIC codes 372, 20 and 73. Also conducts assessments to AS9100 and EN 46000 and TE Supplement. Conducts assessment to TL 9000, VDA 6.1, SA 8000, TickIT, ISO/TS 16949, OSHAS requirements \& Alternative Method.

82) Underwriters' Laboratories of Canada (ULC)

Quality Registry Division

7 Crouse Road

Scarborough, Ontario M1R 3A9 Canada

Phone: (416) 757-3611 (Contact: Vijay Aggarwal/Peter Moore)

Fax: (416) 757-1781

E-Mail: ulcinfo@ulc.ca

URL: www.ulc.ca

OR

Underwriters' Laboratories of Canada (ULC)

Airport Square

Suite $600,1200 \mathrm{~W} .73^{\text {rd }}$ Avenue

Vancouver, British Columbia V6P 6G5 Canada

Phone: (604) 264-1355 (Contact: Chuck Fazackerley)

Fax: (604) 264-1306

E-Mail: none reported

URL: www.ulc.ca

Other Information:

a. Accredited by: SCC (Canada).

b. Other Program Recognition: QS-9000 qualified registrar by Ford/DaimlerChrysler/GM.

c. Services: ULC offers ISO 9000 registration. ULC's registration program includes the full range of registration services of affiliate, Underwriters Laboratories Inc. (UL), the largest U.S.-based ISO 9000 registrar, including internationally recognized ISO 9000 accreditations by SCC, RAB, RvA and UKAS; QS-9000 registration for the automotive industry; and ISO 14000 registration of Environmental Management Systems. Also, ULC offers a full range of product testing and certification services, as well as, 5-day RAB-accredited lead auditor training and 2-day internal auditor training.

83) United Registrar of Systems Ltd. (URS)

1187 S. Grove 
Oak Park, IL 60304

Phone: 1-888-877-8689 (Contact: Sales Services)

Fax: 1-888-877-8689

E-Mail: ursreg@aol.com

URL: www.urs-registrar.com

Other Information:

a. Accredited by: UKAS (U.K.).

b. Other Program Recognition: QS-9000 qualified registrar by Ford/DaimlerChrysler/GM.

c. Services: URS has appointed an Independent Certification Board (ICB), which is constituted of independent and impartial persons who represent the interests of the consumer, industry and legislative bodies. The ICB ensures the operational staff of URS are kept up-to-date on commercial and quality-related issues. URS has offices and agents in the U.S.A., Dominion of Canada, England and Scotland (U.K.).

84) U.S. Testing Company (Now part of SGS International Certification Services, Inc. See SGS entry above.)

85) VCA North America

17250 Newburgh Road, Suite 140

Livonia, MI 48152

Phone: (734) 591-1605 (Contact: Robert M. Brayfield; extension 102)

Fax: (734) 591-1705

E-Mail: r.brayfield@vcana.com

URL: http://www.vca.gov.uk

Other Information:

a. Accredited by: UKAS (U.K.). Accredited by ANSI-RAB for ISO 9001 and ISO 14001.

b. Other Program Recognition: QS-9000 qualified registrar by Ford/DaimlerChrysler/GM. VCA is an automotive industry registrar only. An IATF-recognized certification body.

c. Services: Scope of accreditation includes: glass; glassware; ferrous metals; nonferrous metals; forging; bolts; sintering; locks; brackets; hinges; agricultural machines; press tools; earth moving equipment; mechanical tilting equipment; precision chains; industrial engines; air conditioning; precision components; insulated wire; electrical equipment; cellular telephones; electrical instruments; audio equipment; lamps; motor vehicles; trailers; automobile parts; invalid carriages; tachographs; panel clocks; printing; rubber tires; plastics; wholesale distribution; stock; inspection; repair; mobile radio; road haulage; and technical designs. Note: the head office for VCA is at 1 Eastgate Office Centre, Eastgate 
Road, Bristol, United Kingdom BS5 6XX. Member of IAAR. Conducts assessments to VDA 6.1 - KBA and ISO TS 16949 - SMMT. 


\section{APPENDIX A \\ Contacts for Further Information on Listings}

Information on the ANSI-RAB National Accreditation Program (NAP) and on the registrars that are accredited can be obtained from:

American National Standards Institute (ANSI)

1819 L Street, N.W.

Sixth Floor

Washington, DC 20036

Phone: (202) 293-8020 (Contact: Lane Hallenbeck; Ross Quan)

Fax: (202) 293-9287

E-Mail: rquan@ansi.org

URL: http://www.ansi.org

OR

The Registrar Accreditation Board (RAB)

P.O. Box 3005 or 600 Plankinton Avenue

Milwaukee, WI 53201-3005

Phone: (414) 272-3937, 1-888-722-2440 (Contact: Penny Fredrick)

Fax: (414) 765-8661

E-Mail: rab@rabnet.com

URL: www.rabnet.com

Information on RvA's accreditation program for quality system registrars (as well as on the registrars they have accredited can be obtained from:

Raad voor Accreditatie (RvA)

\{Dutch Council for Accreditation\}

Radboudkwartier 223

P.O. Box 2768

3500 GT Utrecht, The Netherlands

Phone: $011-31-30-239-4500$ (Contact: Peter Tempelman)

Fax: 011-31-30-239-4539

E-Mail: peter.tempelman@rva.nl

URL: http://www.rva.nl

Information on Canada's accreditation programs for quality and environmental management systems registrars (as well as on the registrars they have accredited) can be obtained from:

Standards Council of Canada (SCC)

270 Albert St., Suite 200

Ottawa, Ontario K1P $₫ 7$ Canada

Phone: (613) 238-3222 (Contact: Don Wilson/Hollie Last)

Fax: (613) 569-7808

E-Mail: info@scc.ca 


\section{URL: http://www.scc.ca}

Information on Mexico's accreditation program for quality system registrars (as well as on the registrars that they have accredited) can be obtained from:

Direccion General de Normas (DGN)

Puente de Tecamachalco No. 6 colonia

Lomas de Tecamachalco

Estado de Mexico

C.P. 53950

Mexico

Phone: (525) 729-94-76

Fax: (525) 729-94-84

Telex: 1775840 inceme

Cable: secofi/147

E-Mail: cqm@secofi.gob.mx or avaldez@secofi.gob.mx or cidgn@secofi.gob.mx

URL: www.secofi.gob.mx/dgn1.html

$\mathrm{RAB}$ operates a quality system assessor registration program in the United States, as does the International Register of Certificated Auditors (IRCA). Address RAB inquiries to the address listed above. Address all IRCA inquiries directly to:

International Register of Certificated Auditors (IRCA)

12 Grosvenor Crescent

London SW1X 7EE

United Kingdom

Phone: (0) 2072456833 (Contact: Sancia Brown)

Fax: (0) 2072456755

E-Mail: irca@irca.org; sbrown@irca.org

URL: www.irca.org

Note: IRCA is one of the initial signatories to the International Auditor and Training Certification Association (IATCA) MLAs for mutual recognition of auditor and training course certification.

Contact the following in Britain:

United Kingdom Accreditation Service (UKAS)

Queens Road

Teddington, Middlesex TW11 ONA

United Kingdom

Phone: 44-181-943-6311

Fax: 44-181-943-7134

E-Mail: none reported

URL: none reported 
APPENDIX B

List of Selected Acronyms/Initials

AAR (Association of American Railroads)

ACCSQ (ASEAN Consultative Committee for Standardization/Quality)

AFNOR (Association Francaise de Normalisation)

AIDMO (Arab Organization for Industrial Development \& Mines)

ASMO (Arab Organizations for Standardization and Metrology)

ANSI (American National Standards Institute)

APEC (Asia-Pacific Economic Cooperation)

APEC/SCSC (APEC Subcommittee on Standards and Conformance)

APLAC (Asia-Pacific Laboratory Accreditation Cooperation)

APLMF (Asia-Pacific Legal Metrology Forum)

APMP (Asia-Pacific Metrology Program)

ARSO (African Regional Organization for Standardization)

ASEAN (Association of South East Asian Nations)

ASQ (American Society for Quality)

BELCERT (Belgian Accreditation System)

BIPM (Bureau International des Poids et Mesures)

CARICOM (Caribbean Community and Common Market)

CARIMET (Caribbean Metrology Program)

CASCO (ISO Council Committee on Conformity Assessment)

CEN (European Committee for Standardization)

CENELEC (European Committee for Electrotechnical Standardization)

CIS (Commonwealth of Independent States)

CMN (Mercosur Standardization Committee)

COOMET (Cooperative Organization on Metrology)

COPANT (Comision Paramericana de Normas Technicas)

DAR (Deutscher Akkreditierungs Rat)

DGN (Direccion General de Normas)

DIN (Deutsches Institut fur Normung)

EAC (European Accreditation Cooperation)

EFTA (European Free Trade Association)

EMA (Entidad Mexicana de Acreditacion)

EMAS (European-Eco-Management and Audit Scheme)

EMS (Environmental Management Systems)

EN (European Norm)

EOQ (European Organization for Quality)

EOTC (European Organization for Testing and Certification)

ETSI (European Telecommunications Standards Institute)

EU (European Union)

EUROMET (European Metrology Program)

FAO/CODEX (Food \& Agricultural Organization/Codex)

FSU (Former Soviet Union) 
FTAA (Free Trade Area of the Americas)

GATT (General Agreement on Tariffs and Trade)

GCC (Gulf Cooperation Council)

HACCP (Hazard Analysis Critical Control Point)

HKCBAS (Hong Kong Certification Body Accreditation Scheme)

IAAR (Independent Association of Accredited Registrars)

IAF (International Accreditation Forum)

IAOB (International Automotive Oversight Bureau)

IATCA (International Auditor and Training Certification Association)

IATF (International Automotive Task Force)

IEC (International Electrotechnical Commission)

IECEE/CB (IEC System for Conformity Testing to Standards for Safety of

Electrical Equipment, Certification Bodies Scheme)

ILAC (International Laboratory Accreditation Cooperation)

IMEKO (International Measurement Confederation)

IRCA (International Register of Certificated Auditors)

IQNET (International Quality Certification Network)

ISO (International Organization for Standardization)

ITU (International Telecommunications Union)

JISC (Japanese Industrial Standards Committee)

ЛUNAC (Junta Andina Comision)

KBA (German Department of Transportation/Kraftfahrt-Bundesamt)

MERCOSUR (Mercado Comun del Cono Sur)

MSTQ (Metrology, Standardization, Testing and Quality)

NACB (National Accreditation of Certification Bodies)

NACLA (National Cooperation for Laboratory Accreditation)

NAICS (North American Industry Classification System)

NAFTA (North American Free Trade Agreement)

NAP (National Accreditation Program)

NIST (National Institute of Standards and Technology)

NOM (Norma Oficial Mexicana)

NORAMET (North American Metrology Program)

NQA (National Quality Assurance)

NVLAP (National Voluntary Laboratory Accreditation Program)

OPEC (Organization of Petroleum Exporting Countries)

PAC (Pacific Accreditation Cooperation)

PASC (Pacific Area Standards Committee)

QMS (Quality Management Systems)

QSAR (Quality Systems Assessment Recognition/ISO/IEC)

RvA (Raad voor Accreditatie/Dutch Council for Accreditation)

RAB (Registrar Accreditation Board)

SA (Social Accountability)

SASO (Saudi Arabian Standards Organization)

SCC (Standards Council of Canada)

SIM (Sistema Interamericano de Metrologia)

TAPA (Technology Asset Protection Association) 
TBT (Technical Barriers to Trade)

TGA (Tragergemeinschaft fur Akkreditierung)

VDA (Verband der Automobilindustrie/

German Automotive Industry Association)

WTO (World Trade Organization) 


\section{APPENDIX C}

The following selected organizations and abbreviations are referenced in this publication:

Association of American Railroads (AAR)

ASEAN Consultative Committee for Standardization/Quality (ACCSQ)

Association Francaise de Normalisation (AFNOR)

Arab Organization for Industrial Development \& Mines (AIDMO)

Arab Organization for Standardization and Metrology (ASMO)

American National Standards Institute (ANSI)

Asia-Pacific Economic Cooperation (APEC)

APEC Subcommittee on Standards and Conformance (APEC/SCSC)

Asia-Pacific Laboratory Accreditation Cooperation (APLAC)

Asia-Pacific Legal Metrology Forum (APLMF)

Asia-Pacific Metrology Program (APMP)

African Regional Organization for Standardization (ARSO)

Association of South East Asian Nations (ASEAN)

American Society for Quality (ASQ)

Belgian Accreditation System (BELCERT)

Bureau International des Poids et Mesures (BIPM)

Caribbean Community and Common Market (CARICOM)

Caribbean Metrology Program (CARIMET)

ISO Council Committee on Conformity Assessment (CASCO)

European Committee for Standardization (CEN)

European Committee for Electrotechnical Standardization (CENELEC)

Commonwealth of Independent States (CIS)

Mercosur Standardization Committee (CMN)

Cooperative Organization on Metrology (COOMET)

Comision Paramericana de Normas Technicas (COPANT)

Deutscher Akkreditierungs Rat (DAR)

Direccion General de Normas (DGN)

Deutsches Institut fur Normung (DIN)

European Accreditation Cooperation (EAC)

European Free Trade Association (EFTA)

Entidad Mexicana de Acreditacion (EMA)

European-Eco-Management and Audit Scheme (EMAS)

Environmental Management Systems (EMS)

European Norm (EN)

European Organization for Quality (EOQ)

European Telecommunications Standards Institute (ETSI)

European Union (EU)

European Metrology Program (EUROMET)

Food \& Agricultural Organization/Codex (FAO/CODEX)

*Note: See Appendix B for an alphabetical list of acronyms. 
Former Soviet Union (FSU)

Free Trade Area of the Americas (FTAA)

General Agreement on Tariffs and Trade (GATT)

Gulf Cooperation Council (GCC)

Hazard Analysis Critical Control Point (HACCP)

Hong Kong Certification Body Accreditation Scheme (HKCBAS)

Independent Association of Accredited Registrars (IAAR)

International Accreditation Forum (IAF)

International Auditor and Training Certification Association (IATCA)

International Automotive Task Force (IATF)

International Electrotechnical Commission (IEC)

IEC System for Conformity Testing to Standards for Safety of Electrical Equipment,

Certification Bodies Scheme (IECEE/CB)

International Laboratory . Iccreditation Cooperation (ILAC)

International Measurement Confederation (IMEKO)

International Register of Certificated Auditors (IRCA)

International Quality Certification Network (IQNET)

International Organization for Standardization (ISO)

International Telecommunications Union (ITU)

Japanese Industrial Standards Committee (JISC)

Junta Andina Comision (JUNAC)

German Department of Transportation/Kraftfahrt-Bundesamt (KBA)

Mercado Comun del Cono Sur (MERCOSUR)

Metrology, Standardization, Testing and Quality (MSTQ)

National Accreditation of Certification Bodies (NACB)

National Cooperation for Laboratory Accreditation (NACLA)

North American Free Trade Agreement (NAFTA)

National Accreditation Program (NAP)

National Institute of Standards and Technology (NIST)

Norma Oficial Mexicana (NOM)

North American Industry Classification System (NAICS)

North American Metrology Program (NORAMET)

National Quality Assurance (NQA)

National Voluntary Laboratory Accreditation Program (NVLAP)

Organization of Petroleum Exporting Countries (OPEC)

Pacific Accreditation Cooperation (PAC)

Pacific Area Standards Committee (PASC)

Quality Management Systems (QMS)

Quality Systems Assessment Recognition/ISO/IEC (QSAR)

Raad voor Accreditatie/Dutch Council for Accreditation (RvA)

Registrar Accreditation Board (RAB)

Saudi Arabian Standards Organization (SASO)

Social Accountability (SA)

Standards Council of Canada (SCC)

Sistema Interamericano de Metrologia (SIM)

Technical Barriers to Trade (TBT) 
Technology Asset Protection Association (TAPA)

Tragergemeinschaft fur Akkreditierung (TGA)

Verband der Automobilindustrie/German Automotive Industry Association (VDA)

World Trade Organization (WTO) 


